\section{OPEN ACCESS}

Edited by:

Jared M. Brown,

University of Colorado Anschutz

Medical Campus, United States

Reviewed by:

Bhalchandra Mirlekar,

University of North Carolina at Chapel

Hill, United States

Andreas L. Lopata,

James Cook University, Australia

${ }^{*}$ Correspondence:

Martin Himly

martin.himly@sbg.ac.at

Specialty section: This article was submitted to Inflammation,

a section of the journal

Frontiers in Immunology

Received: 27 November 2019 Accepted: 26 May 2020

Published: 30 June 2020

Citation:

Joubert IA, Geppert M, Johnson L, Mills-Goodlet R, Michelini $S$, Korotchenko E, Duschl A, Weiss R, Horejs-Höck J and Himly M (2020) Mechanisms of Particles in Sensitization, Effector Function and

Therapy of Allergic Disease.

Front. Immunol. 11:1334.

doi: 10.3389/fimmu.2020.01334

\title{
Mechanisms of Particles in Sensitization, Effector Function and Therapy of Allergic Disease
}

\begin{abstract}
Isabella Anna Joubert, Mark Geppert, Litty Johnson, Robert Mills-Goodlet, Sara Michelini, Evgeniia Korotchenko, Albert Duschl, Richard Weiss, Jutta Horejs-Höck and Martin Himly ${ }^{\star}$
\end{abstract}

Division of Allergy and Immunology, Department of Biosciences, University of Salzburg, Salzburg, Austria

Humans have always been in contact with natural airborne particles from many sources including biologic particulate matter (PM) which can exhibit allergenic properties. With industrialization, anthropogenic and combustion-derived particles have become a major fraction. Currently, an ever-growing number of diverse and innovative materials containing engineered nanoparticles (NPs) are being developed with great expectations in technology and medicine. Nanomaterials have entered everyday products including cosmetics, textiles, electronics, sports equipment, as well as food, and food packaging. As part of natural evolution humans have adapted to the exposure to particulate matter, aiming to protect the individual's integrity and health. At the respiratory barrier, complications can arise, when allergic sensitization and pulmonary diseases occur in response to particle exposure. Particulate matter in the form of plant pollen, dust mites feces, animal dander, but also aerosols arising from industrial processes in occupational settings including diverse mixtures thereof can exert such effects. This review article gives an overview of the allergic immune response and addresses specifically the mechanisms of particulates in the context of allergic sensitization, effector function and therapy. In regard of the first theme (i), an overview on exposure to particulates and the functionalities of the relevant immune cells involved in allergic sensitization as well as their interactions in innate and adaptive responses are described. As relevant for human disease, we aim to outline (ii) the potential effector mechanisms that lead to the aggravation of an ongoing immune deviation (such as asthma, chronic obstructive pulmonary disease, etc.) by inhaled particulates, including NPs. Even though adverse effects can be exerted by (nano)particles, leading to allergic sensitization, and the exacerbation of allergic symptoms, promising potential has been shown for their use in (iii) therapeutic approaches of allergic disease, for example as adjuvants. Hence, allergen-specific immunotherapy (AIT) is introduced and the role of adjuvants such as alum as well as the current understanding of their mechanisms of action is reviewed. Finally, future prospects of nanomedicines in allergy treatment are described, which involve modern platform technologies combining immunomodulatory effects at several (immuno-)functional levels.

Keywords: adjuvants, alum, animal dander, house dust mite feces, immunomodulation, mold spores, nanomedicine, pollen 


\section{THE ALLERGIC IMMUNE RESPONSE-BASICS OF THE DISEASE}

Worldwide more than a billion people are suffering from allergic disease (1). As one of the most prevalent chronic respiratory illnesses, allergic rhinitis/conjunctivitis and allergic asthma are estimated to affect up to $30 \%$ of the population in Western countries (2). Not only the quality of life, but also school and work performance are significantly impacted for those afflicted, further making allergy an economic burden. (3-5). Allergic diseases have seen a dramatic increase; while they have been described as rare in the beginning of the 20th century, it is expected that by 2025, half of the European population will be affected $(6,7)$. The observed boost in prevalence of respiratory allergy is associated with several factors associated with the "Western lifestyle," including urbanization, industrialization, agriculture, air pollution, climate change, alterations in biodiversity, increase in personal cleanliness and reduced contact with infectious pathogens $(1,8-10)$. In this context, this review will on the one hand focus on air pollution, and specifically on particulate matter (PM), which is believed to be among the major factors for the increase in allergic disease prevalences. On the other hand, this review will detail how the resulting disease burden manifests upon exposure to common aeroallergens of grass/weed/tree pollen, house dust mite, pet dander, and mold spores.

According to common text book knowledge $(11,12)$ the allergic response is divided into two stages: (i) the sensitization phase, which is accompanied by an immune deviation toward a $\mathrm{T}$ helper (Th)2-type response and is facilitated by allergen-specific Th2 cells secreting the cytokines interleukin (IL)-4, IL-5, and IL-13, ultimately leading to the generation of allergen-specific immunoglobulin $\mathrm{E}$ (IgE) antibodies; in the second stage, (ii) the effector phase, IgEloaded mast cells (MCs) and basophils degranulate upon exposure to the allergen source, resulting in the release of mediators (i.e., histamines, prostaglandins, leukotrienes). Consequently, individuals with respiratory allergies suffer from symptoms typical for rhinoconjunctivitis, such as a runny nose, sneezing, itching, and watery or swollen eyes. More critical symptoms comprise signs of airway hyperresponsiveness (AHR), characterized by shortness of breath, coughing and wheezing. Allergies are commonly diagnosed via clinical anamnesis, skin testing and in vitro methods for quantification of allergen-specific IgE (13). Allergy treatment mostly consists of pharmacological interventions with antihistamine, corticosteroids, MC stabilizers, anti-cholinergic agents and leukotriene inhibitors (14). The only curative treatment, however, is allergen-specific immunotherapy (AIT), which displays success rates of around $80 \%$ for respiratory allergies $(15,16)$. While allergen avoidance remains the most important type of intervention, there are notable limitations concerning inhalable environmental allergens in respiratory allergies. As climate change has extended pollen season, higher pollen counts have been documented in several European countries (17). A German study has furthermore observed an association between ozone levels and reactivity to allergen extracts in skin tests (bigger wheal and flare sizes) (18). Likewise, combustion-derived PM is believed to increase allergic reactions by interacting with pollen, as shown by increases in hospital visits related to pollinosis on days with high PM levels (19).

\section{THE ALLERGENIC ENTITIES-DISCREPANCY BETWEEN MOLECULAR UNDERSTANDING AND CLINICAL REALITY}

Humans are constantly exposed to allergenic substances in the form of particulates releasing biologically active substances, i.e., proteins and other biomolecules which come into contact with the human mucosal tissue. More than 150 pollen allergens originate from environmental sources such as grasses, weeds, and trees and they have been recognized to play a significant role in triggering allergic responses in sensitized individuals $(20,21)$. In addition to seasonally confined outdoor allergens, indoor allergens lead to perennial exposure, which has further implications for the clinical outcome in the affected patients (11). The major cat allergen Fel d 1 was detected in 99.9 and $99.7 \%$ of American homes, respectively, in two large US surveys $(22,23)$. Similar findings were reported for the major dog allergen Can $\mathrm{f} 1$ and detectable levels of the individual group 1 and 2 house dust mite (HDM) allergens were found in $60-85 \%$ of surveyed homes $(23,24)$. Fungal spores are ever present and constitute the biggest proportion of aerobiological PM (25), even exceeding pollen grains (26). The official allergen database (www.allergen.org) of the WHO/IUIS currently lists 961 distinct sequences of allergenic molecules, and many more isoallergens and variants, classified into 852 taxonomic groups (www.allergenonline.org). Interestingly, among the 17,929 currently listed protein families (http://pfam.xfam.org/), allergens only appear in $216 \mathrm{Pfam}$ domains, thus, constituting a share of just 1.3\% (http://www. meduniwien.ac.at/allfam/). A recent report by the European Academy of Allergy and Clinical Immunology (EAACI) has pointed out discrepancies between the molecular definition of allergic sensitization, in the Molecular Allergology User's Guide termed bottom-up approach, and observations made in clinical settings considered as top-down approach (27). Since physicians commonly use natural allergen sources for allergy diagnosis, this implies that the degree of allergenicity is determined not only by the mixture of allergenic proteins itself but by a variety of bystander substances and other cofactors contained in the allergen source. Discrepancy also exists when it comes to the clinical efficacy of allergic treatment by immunotherapy using crude natural extracts or chemically modified preparations, so-called allergoids, vs. highly purified recombinant molecules, while safety concerns clearly direct the way into a future of using recombinant allergens enabling development of genetically modified products with optimized safety profiles termed hypoallergens $(28,29)$. In the present review, we will give a broad overview on the particulate aspects in sensitization, effector function and therapeutic treatment of allergic disease. 

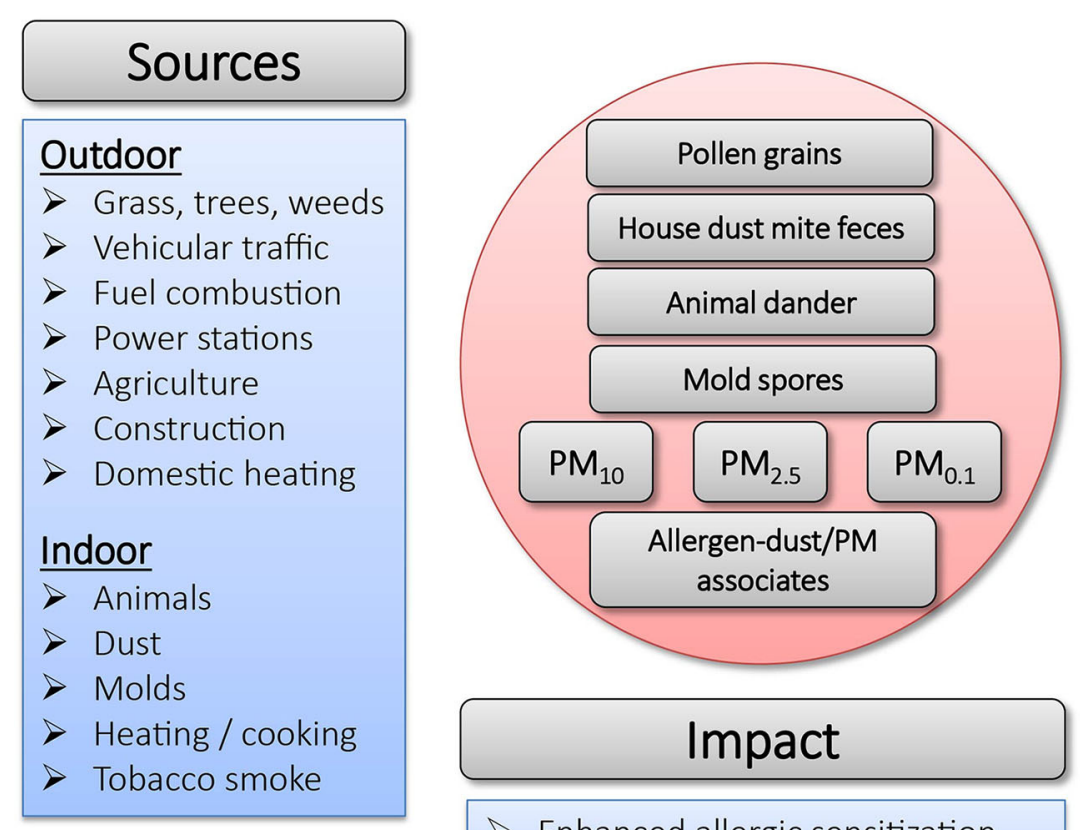

Enhanced allergic sensitization

Exacerbation of allergic rhinitis

Aggravation of asthma symptoms

\section{Targets}

\section{Inhalable fractions}

Upper respiratory tract: (nose, throat, larynx) entire allergen sources $>5 \mu \mathrm{m}, \mathrm{PM}_{10}$

Tracheobronchial tract: (trachea, bronchi, bronchioli) allergen-dust associates $<5 \mu \mathrm{m}, \mathrm{PM}_{2.5}$

Alveolar region $\mathrm{PM}_{0.1}$ and associates

FIGURE 1 | Overview on sources, targets and impact of particulates in allergic sensitization.

\section{THE ROLE OF PARTICULATES IN ALLERGIC SENSITIZATION-WHAT ARE WE EXPOSED TO?}

Exposure to allergens is not only dependent on their environmental distribution, but also on the form in which they become airborne and their aerodynamic properties. Due to their molecular size and vapor pressure, allergenic proteins and glycoproteins cannot become airborne themselves, but instead are either contained inside particulates (e.g., pollen grains), or attach to airborne particles such as dust (i.e., fragments of human keratin or animal epithelium) (30-32). In general, particle-bound allergens smaller than $5 \mu \mathrm{m}$ can stay suspended in the air for longer periods of time (33), while larger ones settle quickly (34). An overview on the sources, the targets and the impact of particles on allergic sensitization is depicted in Figure 1.

The major cat allergen Fel $\mathrm{d} 1$ is produced in sebaceous and salivary glands of cats and is found on its fur, skin and in saliva (35). While the primary source of cat allergens is assumed to come from dander $(36,37)$, Fel d 1 can also be found associated to a range of differently sized dust particles from $<1$ to $20 \mu \mathrm{m}$ (38), some of which can remain airborne for 15-35 min after disturbance (33). The highest concentrations of the major HDM allergen Der $\mathrm{p} 1$ is found in mite feces, whose physical properties are similar to those of pollen grains. De Lucca et al. (39) investigated particles containing HDM allergens and reported size ranges of $15-40 \mu \mathrm{m}$ (feces), $10-150 \mu \mathrm{m}$ (fibers) and
5-50 $\mu \mathrm{m}$ (flakes). Particles of that size can only be deposited on the nasal mucosa and do not enter the lungs. The prevalence of mold is highly dependent on season and climatic factors (humidity, temperature and wind) and their spores have a wide spectrum of different shapes and sizes in the range of $2-250 \mu \mathrm{m}$. A substantial proportion of fungal spores is small enough to enter the lower airways and common allergens are found in the respirable fine particle fraction $(<3 \mu \mathrm{m})$ (40). While pollen grains themselves are large $(10-200 \mu \mathrm{m})(41)$, and only few can reach the lower airways, grass, weed and birch pollen allergens associated with particles under $5 \mu \mathrm{m}$ (starch grains, subpollen particles) have been shown to be released from the pollen grain after light rainfall (42-45). They can furthermore occur in association with smaller airborne fractions such as suspended particulate material deriving from industrial combustion and vehicle exhaust emissions $(46,47)$. Under occupational settings, mixed aerosols containing food-borne allergens have been identified as sources for a higher prevalence of fish allergy in fish-processing workers (48).

Respirable diesel exhaust, indoor soot and dust particulates especially are known for their capability to bind various classes of allergens in vitro and might facilitate their transport into peripheral and deep airways (49-51). Hence, the outcome of allergen exposure is lastly also dependent on the nature of the particle carrying it. Diesel exhaust particles (DEPs), for example, have been shown to contribute to asthma and allergic airway disease (52-55). Binding to carrier particles can furthermore 
enable allergen concentration, increasing their potential for triggering asthma attacks (49). This may explain the importance of combustion-derived PM in the context of allergic disease, as it provides an ideal vehicle for the distribution and uptake of allergens, which would otherwise not reach the lower airways. Furthermore, PM also displays the capacity to modify the immunological reactions against the transported allergen. The latter will be discussed in detail in this review.

For environmental studies of air pollution, PM is commonly divided according to its size (aerodynamic diameter) into different categories: $\mathrm{PM}_{10}$, coarse particles with an aerodynamic diameter $\leq 10 \mu \mathrm{M}, \mathrm{PM}_{2.5}$, fine particles with a diameter $\leq 2.5 \mathrm{~nm}$ and $\mathrm{PM}_{0.1}$, ultrafine particles with a diameter $\leq 0.1 \mu \mathrm{m}$ (56). The size of PM is a crucial factor concerning its capability to penetrate into the respiratory tract: while $\mathrm{PM}_{10}$ is only able to reach the upper respiratory tract, $\mathrm{PM}_{2.5}$ reaches the tracheobronchial tract and $\mathrm{PM}_{0.1}$ is able to penetrate into the alveolar region (57). The composition of PM varies among geography, season and proximity to roadways (58). Various studies have shown that PM exposure is associated with enhanced allergic sensitization and aggravation of asthmatic symptoms (59, 60). Moreover, the exposure to PM during childhood is believed to contribute to the increase in allergies worldwide (61). In the context of allergic disease, PM has furthermore been shown to exert harmful effects as a chemical toxin. Upon inhalation, PM can induce cell stress and toxicity, dependent on its particle size, chemical composition, and surface-bound molecules (62). For instance, PM containing transition metals such as iron have been shown to exert genotoxic effects and increase the production of reactive oxygen species (ROS) $(63,64)$. Furthermore, PM-associated endotoxins can contribute to increased airway inflammation and dysfunction (65) In summary, PM has differential implications on allergic disease by either enhancing allergic sensitization or exacerbating pulmonary symptoms, as will be discussed in further detail in subsequent sections of this review.

Outdoor PM can be derived from various sources such as vehicular traffic, fuel combustion, agriculture or industry, but also non-anthropogenic sources like volcanic eruptions, wildfires or ocean-derived salts. A major component of traffic-related outdoor PM are DEPs, which typically consist of a carbon core that has adsorbed different organic compounds, e.g., polycyclic aromatic hydrocarbons (PAHs), transition metals and other compounds $(66,67)$. The combined effects of air pollution and pollen grains on cells, animal models and allergic patients have been extensively reviewed (68). Different types of particulates were found to be adsorbed to pollen grains (69). DEP-associated PAHs have been shown to exert pro-allergic effects on basophils of birch pollen-allergic patients in an allergen-independent manner (70). Another study has shown that DEPs disrupt the nasal epithelium and thereby lead to the exacerbation of allergic rhinitis symptoms in a mouse model (71). The PIAMA prospective birth cohort study has identified metal constituents of non-tailpipe road traffic emissions such as iron, copper and zinc as risk factors for respiratory disease in school children (72).

Indoor PM is an important factor as most people spend $90 \%$ of their time indoors (73). A major source of indoor PM is tobacco smoke. It accounts for around $50-90 \%$ of the total indoor PM concentration in areas frequented by smokers (57). The particles sizes present in smoke caused by six different commercial available cigarettes was analyzed by Becquemin and co-workers and determined to be $0.27 \pm 0.03 \mu \mathrm{m}$ (inhaled by the smoker) or $0.09 \pm 0.01 \mu \mathrm{m}$ (inhaled by passive smokers) (74). Besides its well-known risk for causing lung diseases in smokers as well as in non-smokers who are exposed to secondhand smoke (75), there is evidence that environmental tobacco smoke is responsible for an increased sensitivity to allergens in children (76). In a birth cohort study, Thacher et al. (77) found that maternal smoking during pregnancy did not relate to sensitization to food allergens. However, exposure to parental smoking during early infancy was shown to increase the risk of food allergen sensitization during childhood and adolescence. Contrasting results were obtained in studies by Shargorodsky et al. (78) who showed that tobacco smoke exposure was related to increased prevalence of rhinitis symptoms, but independent from allergic sensitization in US adults. In another study, a decreased prevalence of allergic sensitization of children was found in respect to tobacco smoke exposure (79). The connection of tobacco smoke and allergy may thus be complex, but it is clear that smoking interferes with immunity at different levels. A review by Maes and colleagues describes that both, tobacco smoke and DEPs, affect allergic sensitization and the development or exacerbation of asthma by similar mechanisms (80) suggesting that the particular characteristics of combustionderived PM can play an important role here.

Co-exposure to PM and specific allergic sensitizers such as pollen, HDM feces, mold spores or animal dander is difficult to study in humans under real-life environmental conditions. The main problem is that sensitization is a highly individual response. Its investigation relies on application of in vitro methods or use of in vivo animal models, which is also how co-exposure has been experimentally addressed (57). A study by Acciani et al. (81) revealed that young $\mathrm{BALB} / \mathrm{c}$ mice display intensified features of allergic sensitization, including an increase of IgE, inflammatory cells, and Th2/Th17 cytokines after co-exposure to DEPs and HDM, while DEPs alone in the same concentration did not lead to the aforementioned effects. A later study by the same researchers reported that combined exposure to DEPs and HDM leads to a significantly higher number of specific memory $\mathrm{T}$ cells in the murine lung promoting secondary responses to the allergen (82). The authors also showed a prolonged presence of DEPs in lung macrophages, but excluded DEPs as the culprits of increased HDM recall responses observed in lymphoid organs. This study illustrates the difficulty in understanding the detailed mechanism and role of particles in the context of allergic disease. Nevertheless, it is clear that DEPs in combination with allergen lead to an exacerbation of the Th2-driven response compared to the effects caused by the allergen alone. The authors, furthermore, proved relevance of their mechanistic investigations in mice for humans by analyzing the Cincinnati Childhood Allergy and Air Pollution Study birth cohort resulting in positive association of increased asthma prevalence in allergic children with early-life exposure to high DEP levels compared to nonallergic children. Castaneda and colleagues strengthened these mechanistic findings by showing that PM enhanced allergic 


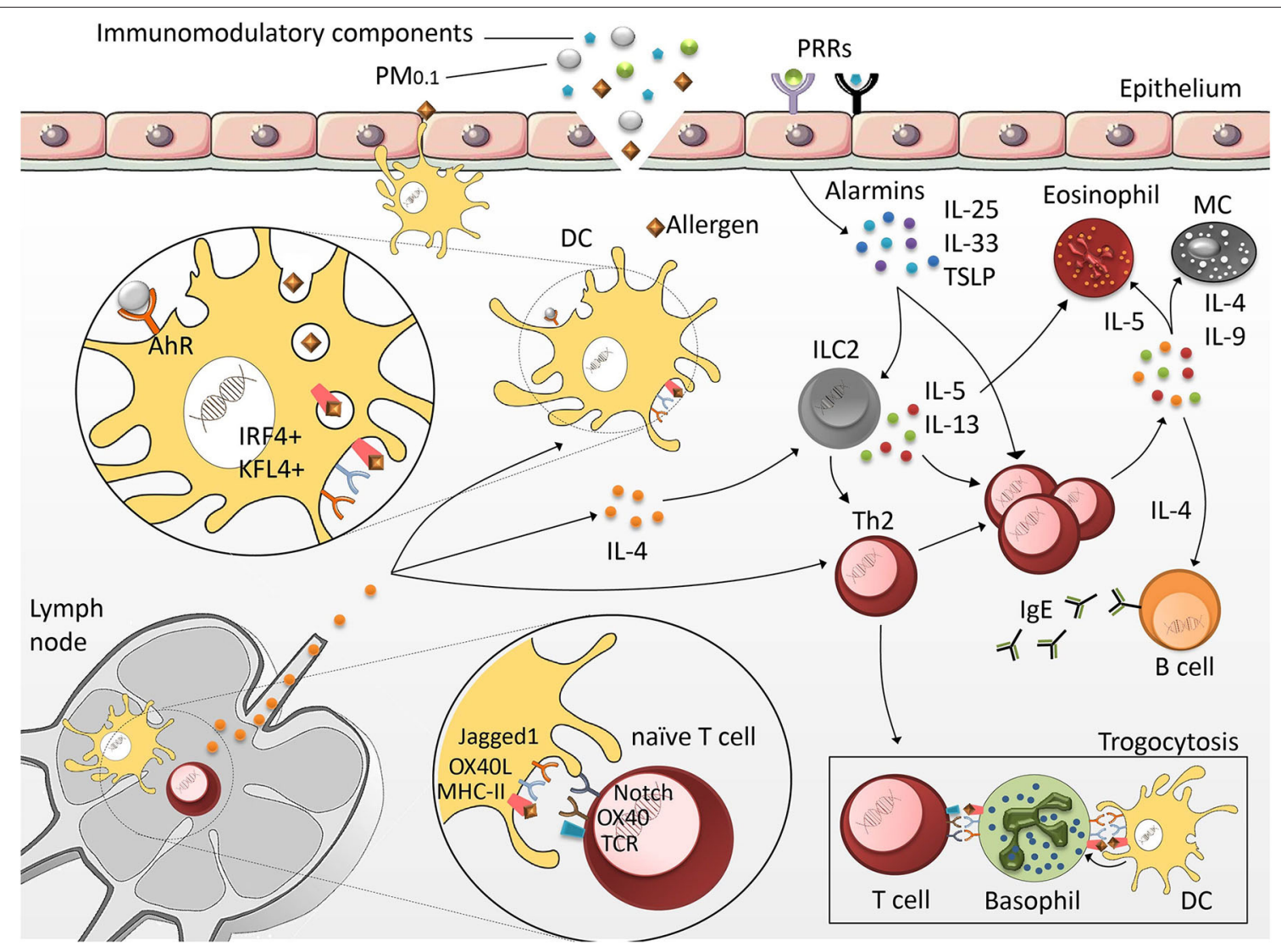

FIGURE 2 | Mechanisms of allergic sensitization. DCs located in the epithelia of peripheral tissues are exposed to allergens, immunomodulatory compounds and particulate matter (PM). Once activated, highly specialized CD11 ${ }^{+} / \mathrm{CD} 301^{+} / \mathrm{PDL} 2^{+} / \mathrm{KFL} 4^{+} / \mathrm{RRF} 4^{+} \mathrm{DCs}$ migrate into the lymph nodes to initiate the Th2 differentiation program. Upon exposure to epithelial-derived factors (IL-25, thymic stromal lymphopoietin (TSLP) and IL-33), group 2 innate lymphoid cells (ILC2) produce Th2 cytokines. This further promotes Th2 cell polarization and leads to exacerbation of the allergic response characterized by the secretion of IgE by B cells, and the activation of MCs and eosinophils. Basophils act as antigen-presenting cells (APCs) by presenting DC-derived antigenic peptides to T cells via a specific membrane transfer mechanism called trogocytosis.

immune responses of Balb/c mice, characterized by increased monocyte and eosinophil migration, Th2 cytokines and IgE expression (83). They, furthermore, suggested that PAH contents are responsible for Th17 immune responses by activation of the aryl hydrocarbon receptor. Taken together, it is likely that both particle-specific effects as well as effects exerted by PMassociated chemicals play a role in the enhanced immune responses observed upon co-exposures.

\section{IMMUNE CELLS INVOLVED IN ALLERGIC SENSITIZATION-HOW DO THEY REACT TO PARTICLES?}

The mechanisms underlying allergic sensitization in general, and upon exposure to particulate matter, are still not fully understood. Recently it has been shown that sensitization toward certain allergens may not primarily result from intrinsic properties of the allergen itself, but can also depend on immunomodulatory compounds co-delivered with the allergen $(84,85)$. To better understand the complex process of allergic sensitization, the following section gives a brief overview on the different types of immune cells, their interactions, and their possible role as triggers of particle-mediated allergic reactions.

Dendritic cells (DCs) play a crucial role in priming specific $\mathrm{T}$ cell responses (Figure 2). They are located close to the epithelial barriers, where they are exposed to allergens, allergenassociated immunomodulatory components and particulate matter. Once activated by the respective stimulus, DCs undergo a specific maturation process, which primes them to promote the differentiation of naïve $\mathrm{CD} 4{ }^{+} \mathrm{T}$ cells into Th2 cells (86). While DCs can release $\mathrm{T}$ cell-priming cytokines that determine the type of immune responses, IL-4, the classical Th2-priming cytokine, is not produced by DCs. This raises the question whether, in the absence of alternative Th cell-priming stimuli, DCs would induce a Th2 phenotype by default. Another hypothesis states that DC-derived stimuli, other than IL-4, can potently induce Th2 differentiation as well. One example are DCs, which are characterized by the expression of $\mathrm{CD}_{11} \mathrm{~b}^{+} \mathrm{CD} 301 \mathrm{~b}^{+}$ $\mathrm{PDL}_{2}{ }^{+}$. These cells are particularly potent activators of Th2 
cell differentiation and further enhance their Th2-polarizing capacity by expression of the costimulatory molecules OX40L and Jagged 1 (87-90). Especially upon exposure to fine particles and ultrafine particles, the Jagged $1 /$ Notch signaling axes is essential for allergic inflammation (91). Jagged 1 interacts with Notch receptors on $\mathrm{T}$ cells, which can promote Th2 cell polarization via induction of GATA-3 $(92,93)$. This mechanism is particularly important in $\mathrm{PM}_{0.1}$-induced allergic inflammation of the airways. $\mathrm{PM}_{0.1}$-dependent transcriptional expression of Jagged $1(91,94)$ seems to be regulated via the aryl hydrocarbon receptor, which in turn is activated by $\mathrm{PAH}$ contained in the particles. Thus, $\mathrm{PM}_{0.1}$-induced Jagged 1 transcription depends on aryl hydrocarbon receptor, but is independent of classical pattern recognition via Toll-like receptor (TLR)4 and NOD-like receptors (NLRs) (94). Neutralizing Notch-signaling downstream of Jagged 1/Notch interactions further demonstrated that $\mathrm{PM}_{0.1}$-induced exacerbation of allergic airway inflammation was abrogated (91). This points toward a crucial involvement of the Jagged/Notch pathway in promoting particle-mediated Th2 immune responses.

In addition to OX40L and Jagged 1, it was shown that DCs capable of inducing Th2 responses also require Interferon regulatory factor 4 (IRF4) and Krüppel-like factor 4 (KLF4). Mice with IRF4 deficiency in the DC lineage show a strongly reduced

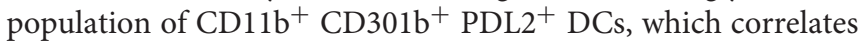
with a strong reduction of allergen-induced lung inflammation $(95,96)$. Conditional KLF4 deletion within conventional CD $8 \alpha^{+}$type DCs provided evidence that KLF4 is required to promote Th2 cell responses induced upon HDM challenge or helminth infection, whereas KLF4 deletion did not affect Th1 or Th17 responses in other infection models (97). These experiments suggest that KLF4 is an important molecule enabling DCs to promote Th2 immunity.

Although DCs are the most important cell type contributing to the development of type 2 responses, naïve Th cells also receive important signals from epithelial barrier organs. Allergen contact, protease activity of certain allergens, and cell damage can result in the release of cytokines and alarmins including IL-25, thymic stromal lymphopoietin (TSLP) and IL-33 from epithelial cells (98). Th2 cells upregulate the receptors for these cytokines, indicating that priming as well as re-activation of Th2 cells is strongly promoted by those factors $(99,100)$. Especially at sites of inflammation, IL-25, IL-33, and TSLP facilitate terminal differentiation of Th2 cells and foster their effector functions (101).

The inability of DCs to produce IL-4 has drawn the attention to basophils, which produce substantial amounts of IL-4. Murine basophils additionally express MHC class II as well as the costimulatory molecules CD80 and CD86, indicating that these cells might be able to initiate the process of Th2 differentiation (102). However, human studies failed to confirm the important role of basophils in priming Th2 differentiation $(103,104)$ and later studies have shown that inflammatory $\mathrm{CD}_{11} \mathrm{~b}^{+}$conventional DCs, rather than basophils, are crucial for the initiation of Th2 responses (105). The role of basophils in priming the Th2 response is now explained via trogocytosis. This is a process through which cells (in this case basophils) extract membrane fragments from neighboring cells (in this case DCs), thereby passively acquiring peptide-MHC class II molecules from DCs, to control Th2 development as antigen-presenting cells (APCs) (106).

Group 2 innate lymphoid cells (ILC2s) also play an important role in the induction and maintenance of immune responses mediated by Th2 cytokines. Since ILC2s do not express rearranged antigen receptors or pattern recognition receptors, they are mainly activated by signals derived from the epithelial barrier, including IL-25, IL-33, and TSLP (107). Similar to Th2 cells, ILC2s are characterized by high expression of the transcription factor GATA3 (108), which simulates the transcription of IL-5 and IL-13 (109, 110). In animal models of allergic asthma, ILC2s were identified as the major source of IL-5 or IL-13 (111). Upon stimulation with Heligmosomoides polygyrus, ILC2s can also secrete IL-4 in a Leukotriene D4dependent way. Specific deletion of IL-4 from the ILC2 compartment abrogated the Heligmosomoides polygyrus-induced Th2 response, indicating that ILC2-derived IL-4 was sufficient to promote a Th2 response in this model (112). Thus, synergistic effects between ILC2s and Th2 cells may be required to achieve maximum release of $\mathrm{Th} 2$ cytokines.

\section{AGGRAVATION OF ALLERGIC ASTHMA BY INHALED AEROSOLS}

Asthma can generally be described as hyperresponsiveness and obstruction of the airways caused by chronic inflammation and an overproduction of mucus (113). Although asthma tends to be a lifelong condition, its severity can vary throughout the patient's life. Chronic inflammation is facilitated by the infiltration of a collection of inflammatory cells including eosinophils, MCs and $\mathrm{CD} 4^{+} \mathrm{T}$ cells (114). While $\mathrm{T}$ cells are known to express Th2-type cytokines associated with the aggravation of asthma symptoms (115-117), they can also play a role in regulating the Th2 response and hence, alleviate allergic diseases (118-122). Worldwide, $\sim 300$ million individuals are affected by asthma, with its prevalence increasing over the last decades $(123,124)$. However, some studies have suggested that the prevalence of asthma might have reached a plateau in Western countries (125128). Among the multiple clinically identified types of asthma, allergic asthma is the most common (129-131).

Many different external factors have been associated with the exacerbation of asthma symptoms, including viral infections and exposure to air pollutants $(53,132,133)$. Immunological effects exerted by particulates heavily depend on the tested material as their immunomodulating properties vary with material chemistry as well as size, shape, and surface-properties (134-137). Consequently, it is essential to evaluate individual particulates and avoid generalizations on the basis of single attributes. Silica NPs have been shown to increase the number of eosinophils found in the bronchoalveolar lavage fluid (BALF) in an ovalbumin (OVA)-asthma model (138) and to raise serum IgE titers (139). Furthermore, enhanced AHR and modulation of inflammatory cytokines and chemokines was observed. This 
modulation mainly consisted of an increase in the asthmaassociated cytokines IL-4, IL-5, and IL-13 in response to the application of OVA-silica NP conjugates and was not observed for OVA alone $(140,141)$. Carbon NPs have also been shown to affect mouse asthma models. Carbon black NPs given in conjunction with OVA increased inflammatory- and antigenpresenting cell counts in the lung in an OVA-mouse model $(142,143)$.

It is worth mentioning that silver NPs have been shown to mitigate asthma and decrease the levels of IL-4, IL-5, IL-13, and NF- $\kappa$ B in addition to lowering AHR in OVA-induced allergic inflammation mouse models $(144,145)$. Although various studies demonstrate the suppression of allergic responses by silver NPs, they have also been shown to increase neutrophilia and levels of circulating TNF- $\alpha$ in an allergen-independent context $(146,147)$. However, it is important to note that effects observed for silver NPs could, at least in part, be attributed to the dissolved fraction of the material, as $\mathrm{Ag}^{+}$ions are known to be biologically active $(148,149)$. In the case of lung exposure, different results were observed between silver $\mathrm{NPs}$ and $\mathrm{Ag}^{+}$ions using instillation experiments in mice (150). These findings might be further substantiated by a study from Seiffert et al. (151) which implied that interactions with lung surfactant provides a stabilizing effect on the NP surface preventing the release of $\mathrm{Ag}^{+}$ions.

Studies on the effects of gold NPs on asthma show contradicting results and are dependent on the asthma model used. Gold NPs were found to increase AHR and the neutrophil/macrophage count in BALF in a toluene diisocyanateinduced asthma model (152). PEGylated and citrated gold NPs, however, decreased the mucus production, cytokine levels and inflammatory cell accumulation in the lung in an OVA-asthma model $(153,154)$.

Not only single pristine particle sources can have an effect on asthma exacerbation. It has been shown that ambient air-derived $\mathrm{PM}_{2.5}$ can aggravate asthmatic symptoms in an OVA-asthma mouse model. Studies have shown that $\mathrm{PM}_{2.5}$ in conjunction with OVA increased the levels of Th2 cytokines, AHR, and the number of eosinophils and neutrophils in BALF (155-157). $\mathrm{PM}_{2.5}$ had been obtained by filtering ambient air followed by up-concentration, however, the exact chemical composition was not elucidated. One of the studies attributed the elevated AHR to an increase in apoptosis and TIM-1 activation, which was also witnessed in the OVA/ $\mathrm{PM}_{2.5}$ group (156). Another study has shown that prolonged exposure to high concentrations of $\mathrm{PM}_{2.5}$ leads to an increase in AHR, which was linked to necroptosis-induced neutrophils as well as IL-17 production (158). $\mathrm{PM}_{2.5}$ are not only linked to the induction and increase of asthmatic symptoms in animal models, but have also shown to be associated with a higher frequency of emergency room visits upon human exposure to wildfire-related particulate matter (159, 160). Moreover, controlled human exposure studies have shown an association between DEP-allergen exposure and an increase in IL-5, eosinophil cationic protein and airway eosinophils (161). Interestingly, females and adults over the age of 65 years are suggested to be more susceptible to smoke-derived $\mathrm{PM}_{2.5}$, indicated by a comparably higher number of ER visits in these cohorts (160).
A possible explanation for the health impacts exerted by particulate matter, and carbon black in particular, is its potential to modify methylation patterns. Sofer et al. (162) for instance, have shown a correlation between carbon black and sulfate particle exposure and changes in methylation patterns in the asthma pathway. The identified affected genes were coding for the high-affinity IgE receptor alpha and gamma subunits, the major basic protein of eosinophil granules, and for IL-9 (162). Nadeau et al. (163) also demonstrated a link between exposure to particulate matter and methylation. In their study, exposure to ambient air pollution was associated with hyper-methylation in the Foxp3 locus, which impairs regulatory T cell (Treg) function and in turn increases asthma morbidity (163).

Additionally, indoor particulates in the fine $\left(\mathrm{PM}_{2.5}\right)$ and coarse $\left(\mathrm{PM}_{10}\right)$ range have been shown to directly affect asthmatic symptoms. This was demonstrated by two different studies, which were able to link elevated levels of indoor PM to an increase in asthmatic symptoms and the use of rescue medication in children $(164,165)$. Long-term as well as short-term exposure to PM has an impact on the aggravation of asthmatic symptoms. This was illustrated by a study showing a decrease in $\mathrm{FEV}_{1}$ (Forced Expiratory Volume in 1 second) and an increase of neutrophilic lung inflammation determined in asthmatic patients already after a $2 \mathrm{~h}$ walk along a polluted street in London (166). Moreover, indoor dust biological ultrafine particles, which are mainly composed of microbial extracellular vesicles, have been shown to induce neutrophilic inflammation and, thus, contribute to pathogenesis of chronic lung diseases, such as asthma, chronic obstructive pulmonary disease, and lung cancer (132). In this regard, extracellular vesicles in indoor dust may be recognized as important diagnostic and therapeutic targets. The following sections will first address the allergen-specific and, later, the particle-related aspects of immune deviation as well as the potential of nanomaterials as carrier platforms in allergy treatment.

\section{ALLERGEN-SPECIFIC IMMUNOTHERAPY}

Allergen avoidance and pharmacotherapy aim to build a first line of defense and relieve symptoms of allergy (167-169). However, pharmacotherapy does not prevent allergic disease progression and has to be administered as long as symptoms prevail (170), which typically translates into life-long treatment. The efficacy of allergen avoidance is not supported by robust evidence (171) and is furthermore not feasible in every case (172). So far, AIT is the only curative treatment for allergic diseases as it reinstates immune tolerance against allergens (173).

First described by Leonard Noon and John Freeman in the early 20th century (174), AIT is a highly effective treatment for individuals suffering from IgE-mediated diseases (175-177). The primary goal of AIT is the inhibition of both early- and late-phase allergic responses, which are regulated by a plethora of cellular and molecular events (Figure 3). Three main mechanisms are suggested to lead to the induction of tolerance after successful treatment, differentiating AIT from other vaccines: (i) immune deviation toward a Th1-oriented response (and reduction of 


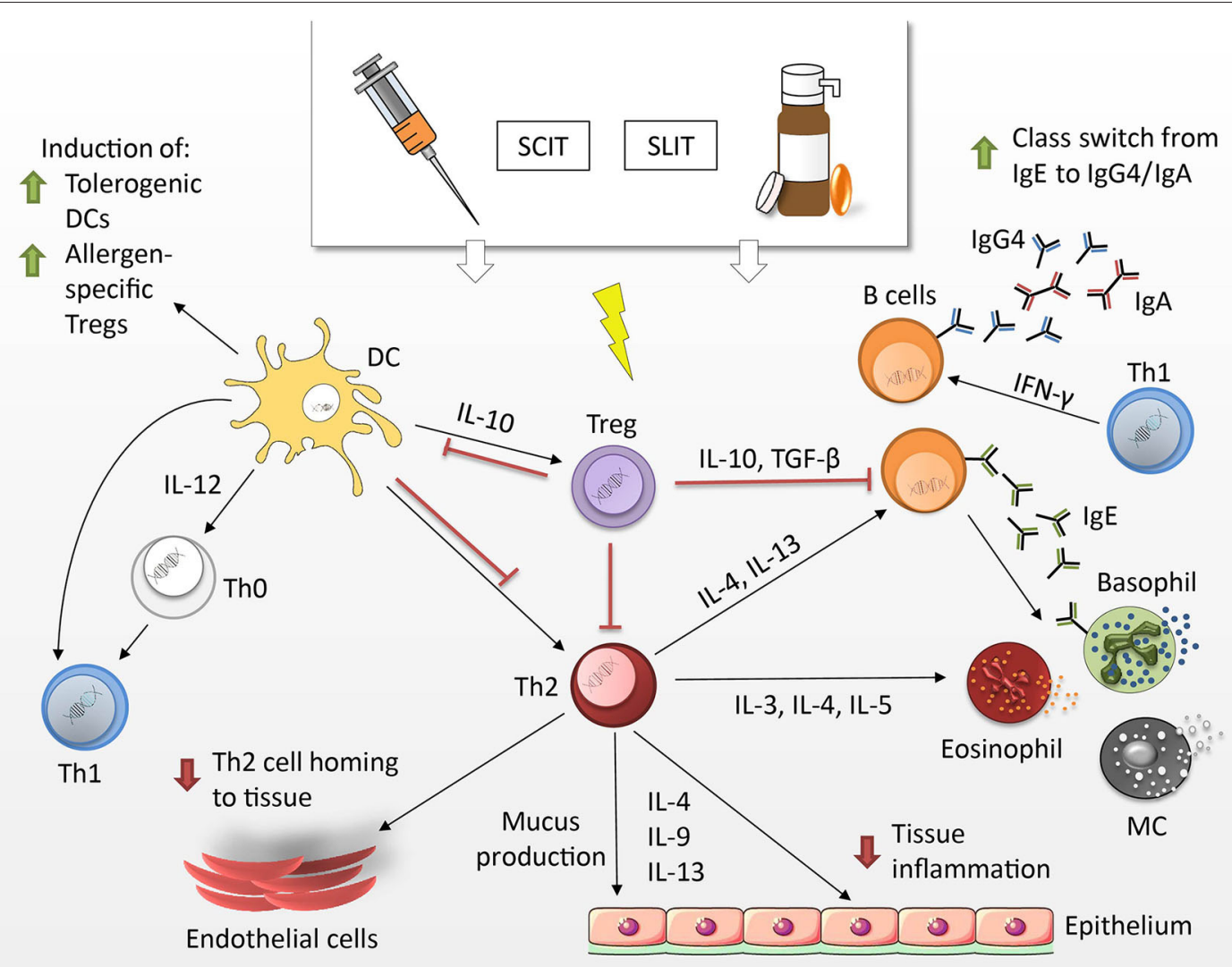

FIGURE 3 | Mechanisms of allergen-specific immunotherapy. Tregs produce cytokines such as IL-10 and TFG- $\beta$, which have the potential to suppress Th2 responses. Upon induction of tolerogenic DCs Th1 are mobilized at the expense of Th2 cells. They produce IFN- $\gamma$ and stimulate the production of IgG4 and IgA antibodies by means of class switching. IgG4 antibodies can block allergen-induced MCs, basophils and eosinophils and hence, limit allergic symptoms by decreasing mediator release $(178,179)$.

atopy-associated Th2 responses); (ii) production of allergenspecific IgG4 antibodies and (iii) induction of Tregs and regulatory B cells, $(173,180,181)$.

AIT can be administered to adults and children via the subcutaneous (SCIT)- or sublingual (SLIT) route. SCIT treatments consist of an initial up-dosing phase, in which increasing doses of allergen are administered to carefully assess the patient's individual sensitivity and the maximum-tolerated dose. This allergen dose is then continued throughout the maintenance phase. Individual shots have to be given with a physician present, due to the risk of adverse effects, which can range from local site reactions to systemic reactions, such as anaphylaxis (182). Sublingual routes for IT have been first proposed in 1986 (183) and facilitate the mucosal deposit of the allergen in the form of drops or dissolving tablets/capsules under the tongue. While this route has been tested in clinical trials in the US, only a few SLIT products have yet been approved by the U.S. Food and Drug Administration (FDA) (184). In general, SLIT is associated with a favorable safety profile, lower risks and offers patients the convenience of an at-home and injection-free administration. It has been suggested that it requires the continuous administration of SCIT/SLIT for 3 years to achieve immunological changes consistent with allergenspecific tolerance in allergic rhinitis, which can be sustained for at least 2 to 3 years after treatment cessation (185).

Although AIT has been well-established and shows successful curation of allergic rhinitis and asthma in many cases, treatments are generally costly, time-consuming and only a few allergens have been standardized for SCIT and SLIT. In recent years, several novel administration routes have been under investigation, including intralymphatic (ILIT), epicutaneous (EPIT), and intradermal (IDIT) routes (186-189). Furthermore, intensive research is focusing on allergoids (i.e., chemically modified/crosslinked allergen particles), allergenfragments, fusions, hybrids and biological immune responsemodifiers for new vaccines to provide a safe, persistent and lifelong cure of allergic disease $(188,190-197)$. In several of the before-mentioned approaches, an interrelation between allergenspecific and particle-related aspects can be observed. In the subsequent chapters, we will therefore dicuss the impact of particles on immune modulation, which is mediated by the specific nature of the particle as adjuvants in AIT. 


\section{MECHANISMS OF ADJUVANTS - THE CLASSICAL CASE OF ALUMINUM HYDROXIDE}

During AIT, adjuvants are often used to modify the immunological and pharmacological efficacy of the vaccine. The use of adjuvants can reduce the required dose of allergen, consequently lowering treatment cost and increasing patient compliance (198). The first generation of adjuvants includes mineral salts such as aluminum hydroxide (alum, i.e., particulates $>1 \mu \mathrm{m}$ ) and calcium phosphate (i.e., particles in nano-micro range), which are the prototypical and most commonly used adjuvants. Second generation adjuvants used in vaccines include TLR agonists, probiotics, small molecules and particulate systems, which aim to induce a shift in the already established immune response toward a Th1- and Treg-dominated activity (199). Even though adjuvants have been used in allergy vaccines since the early 20th century, the full extent of their mechanisms of action still remains to be elucidated.

\section{Improvement of Allergen Uptake}

Adjuvants like alum, which essentially consist of particles, can per se improve the cellular uptake of the allergen by either acting as a delivery vehicle or by helping to efficiently target APCs. Gupta et al. (200) report on the mechanism by which alum-adsorbed antigens are readily phagocytosed by DCs, hence increasing the uptake of antigen. Furthermore, NPs have been shown to improve the uptake of antigen in bone-marrow derived cells (BMDCs) (201), which is attributed to the small size and large surface area of NPs contributing to their easy capture and internalization (202).

\section{Augmenting Immunogenicity}

One of the main functions of adjuvants is enhancing the immunogenicity of the administered allergen, i.e., to deviate the immune response from Th2- to a Th1- and Tregdominated milieu, which can be measured by the resistance to endolysosomal proteolysis (203), upregulation of cytokines such as IL-10 (204), IL-12, IFN- $\gamma$, and downregulation of cytokines IL4, IL-5, IL-13 (205). Furthermore, small molecules like vitamin D3 (206) and aspirin (207) used as adjuvants, have been reported to induce Treg cells. Similarly, alum initiates a Th1 response by the activation of the NLRP3 inflammasome, which further induces the production of IgG antibodies (208). TLR4 agonists such as monophosphoryl lipid A have been found to exhibit a strong potential to induce allergen-specific IgG antibodies (209). Moreover, biodegradable PLG NPs have been shown to enhance antigen-specific immune tolerance without the induction of a Th2 response (210).

\section{Reduction of Antigen Dose/Number of Immunizations Needed for Protective Immunity}

AIT doses can be decreased if the adjuvant-associated allergen forms a depot at the site of administration, leading to its release in a controlled fashion. Alum, as well as various particulate delivery systems have been shown to form such depots and deliver antigens over a long period of time. This depot effect prolongs and sustains the allergen-specific antibody titres and, thus, can enhance the antigen uptake and presentation $(211,212)$.

Although many adjuvants have been developed for vaccines, only a few have been extensively considered for AIT (213). Marketed allergy vaccines usually contain adjuvants like alum, calcium phosphate, microcrystalline tyrosine, and monophosphoryl lipid A. Table $\mathbf{1}$ lists various adjuvants used in AIT.

Alum is approved for a wide spectrum of human vaccines and has a long history of use, particularly in subcutaneous immunotherapy (SCIT) (199). It is simple in preparation, has a good stability and has been shown to enhance the immunogenicity of allergens. During AIT, allergens are strongly adsorbed onto the surface of alum either through electrostatic interactions, ligand exchange or hydrophilic-hydrophobic interactions, which lead to the formation of particulate matter (218). This particulate matter can then be easily phagocytosed by the APCs at the injection site, commencing the immune reaction. Most alum preparations contain small crystalline structures, which can destabilize lysozymes upon phagocytosis by inducing the secretion of agents such as heat shock protein (HSP)-70 (219), cathepsin (220), and potassium ions (221) into the cytosol. This prompts the activation of the NLRP3 inflammasome, resulting in the secretion of pro-inflammatory cytokines and the subsequent production of allergen-specific antibodies (220). Alum has furthermore been shown to induce the release of self-DNA, leading to cytotoxicity at the site of administration (222). This release of self DNA can activate either and IRF3-dependent or IRF3-independent pathway, resulting in the production of allergen-specific IgG or IgE antibodies (217).

\section{Unwanted Side Effects Associated With Alum in AIT}

While alum is generally well-tolerated in small amounts, AIT treatments are lengthy and require frequent vaccinations (up to 16 injections within the first year of treatment) (223). Thus, there is a greater chance of developing certain adverse reactions, such as urticaria, myalgia, chronic fatigue and cognitive dysfunction in susceptible individuals. There is also an increased probability for the accumulation of aluminum salts at the site of administration, which can lead to macrophagic myofascitis (224). In some cases, alum has furthermore been reported to induce a Th2biased immune response $(225,226)$ and can, thus, counteract the therapeutic mechanism of AIT.

Only a small number of studies have so far reported on the toxicity and adverse reaction of alum in immunotherapy. Hence, there is still a huge gap of knowledge, regarding the safety, toxicity, and mode of action of aluminum-based adjuvants in immunotherapy.

\section{NANOPARTICLES-AN ALTERNATIVE ADJUVANT TO ALUM}

Targeting APC with allergens incorporated into or introduced on the surface of NPs is an alternative approach to the use of alum-based adjuvants for AIT (Figure 4). Due to their 
TABLE 1 | Overview on formulations in currently marketed SCIT vaccines in Europe.

\begin{tabular}{|c|c|c|c|c|}
\hline Product & Allergens & Adjuvant & Manufacturer & Reference \\
\hline \multicolumn{5}{|c|}{ NON-MODIFIED ALLERGEN PREPARATION } \\
\hline Alutard $\mathrm{SQ}^{\circledR}$ & $\begin{array}{l}\text { Pollen, HDM, animal } \\
\text { epithelia, insect venom }\end{array}$ & Alum & ALK-Abello & $(214)$ \\
\hline Depot-HAL ${ }^{\circledR}$ F.I.T. & $\begin{array}{l}\text { Pollen, HDM, animal } \\
\text { epithelia, molds }\end{array}$ & Alum & Hal Allergy & https://www.hal-allergy.com \\
\hline Novo-Helisen ${ }^{\circledR}$ Depot & $\begin{array}{l}\text { Pollen, HDM, animal } \\
\text { epithelia, molds }\end{array}$ & Alum & Allergopharma & $\begin{array}{l}\text { https://compendium.ch/mpro/mnr/1072/html } \\
\text { https://www.allergopharma.com/ }\end{array}$ \\
\hline $\begin{array}{l}\text { Pangramin }{ }^{\circledR} \text { Depot A } \\
\text { Plus B }\end{array}$ & Pollen, HDM & Alum & Alk-Abello & https://www.alk.de \\
\hline Tyro-SIT & $\begin{array}{l}\text { Pollen, HDM, animal } \\
\text { epithelia, molds }\end{array}$ & Microcrystalline tyrosine & Bencard Allergie GmbH & https://www.bencard.com \\
\hline Venomenhal $^{\circledR}$ & Insect venom & - & Hal Allergy & https://www.hal-allergy.com \\
\hline \multicolumn{5}{|c|}{ CHEMICALLY MODIFIED ALLERGEN PREPARATION } \\
\hline Acaroid $^{\circledR}$ & HDM & Alum & Allergopharma & https://clinicaltrials.gov/ct2/show/NCT00263640 \\
\hline Acarovac $^{\circledR}$ & HDM & Monophosphoryl lipid A & Bencard Allergie GmbH & https://www.bencard.com \\
\hline Allergovit ${ }^{\circledR}$ & Pollen & Alum & Allergopharma & https://clinicaltrials.gov/ct2/show/NCT00263601 \\
\hline Alustal $^{\circledR}$ & $\begin{array}{l}\text { Pollen, HDM, animal } \\
\text { epithelia, molds }\end{array}$ & Alum & Stallergenes & $(215)$ \\
\hline Alutek $^{\circledR}$ & $\begin{array}{l}\text { Pollen, HDM, animal } \\
\text { epithelia }\end{array}$ & Alum & Inmunotek & https://www.inmunotek.com \\
\hline Alxoid $^{\circledR}$ & $\begin{array}{l}\text { Pollen, HDM, animal } \\
\text { epithelia }\end{array}$ & Alum & Inmunotek & https://www.inmunotek.com \\
\hline Clustoid $^{\circledR}$ & $\begin{array}{l}\text { Pollen, HDM, animal } \\
\text { epithelia }\end{array}$ & Alum & Inmunotek & https://www.inmunotek.com \\
\hline Clustoid $^{\circledR}$ & Pollen, HDM & Alum & Roxall & $(216)$ \\
\hline Depigoid $^{\circledR}$ & Pollen, HDM & Alum & Leti Pharma GmbH & https://alergia.leti.com \\
\hline Phostal ${ }^{\circledR}$ & $\begin{array}{l}\text { Pollen, HDM, animal } \\
\text { epithelia, molds }\end{array}$ & Alum & Stallergenes & $(215)$ \\
\hline Pollinex Quattro ${ }^{\circledR}$ & Pollen & Monophosphoryl lipid A & Bencard Allergie GmbH & $(217)$ \\
\hline
\end{tabular}

size, NPs are efficiently taken up at the site of immunization. Additionally, APCs have a variety of receptors on the cell surface and their targeting orchestrates the cell activation status and the later immune polarization. Therefore, implementation of specific receptor ligands (e.g., carbohydrates) into vaccine delivery systems, may not only facilitate internalization, but also modulate the subsequent immune response.

Resident skin dendritic cells form different subsets based on expression of surface receptors. Moreover, targeting of specific receptors leads to specific DCs activation determining $\mathrm{T}$ cell function. For example, activated epidermal Langerin ${ }^{+}$ DCs promote cytotoxic immune response and can be targeted via DEC-205. Human dermal $\mathrm{CD}_{1}{ }^{+}$DCs express $\mathrm{MGL}$ (macrophage galactose-type C-type lectin), MR (mannose receptor), DEC-205 and DC-SIGN. Targeting of these receptors activates DCs driving $\mathrm{CD}^{+} \mathrm{T}$ cell proliferation $(227,228)$. $\mathrm{CD}_{14}{ }^{+}$dermal DCs express high levels of DC-SIGN and are important for generation of follicular Th cells and hence efficient antibody production. Oral administration of vaccines can target gut mucosal DCs. Depending on the environment, these $\mathrm{CD}_{103^{+}}{ }^{+} \mathrm{DCs}$ can be either tolergenic or pro-inflammatory under inflammatory gut conditions (229). $\mathrm{CD}_{103}{ }^{+} \mathrm{CD}_{11 \mathrm{~b}}{ }^{+}$have also been shown to be critical for Th17 induction (230). Thus, tailor made immune responses can be induced by targeting specific DC subsets via their respective receptors. A more detailed discussion on the link between DCs and T cell functions can be found elsewhere (231).

Nanomaterials are convenient systems for the introduction of functional modifications and are able to combine antigenic and adjuvant properties.

Due to their different physical and chemical properties, NPs have the ability to improve the efficacy of AIT. Here we discuss different particle types currently in either the preclinical or clinical testing phase (e.g., glycoconjugates and virus-like particles) and their potential for immunotherapy.

\section{Carbohydrate Nanoparticles}

Polysaccharides are components of fungal and bacterial cell walls and are recognized by receptors on APCs, which in turn induce strong immune responses against these pathogens. Allergy vaccines containing carbohydrates-ligands of innateimmune receptors-are more efficiently taken up by APCs, not only due to their receptor-mediated internalization, but also their particulate nature. Additionally, via specific receptor targeting, allergen carbohydrate NPs induce stronger responses compared to native proteins and can modulate the immune polarization. 


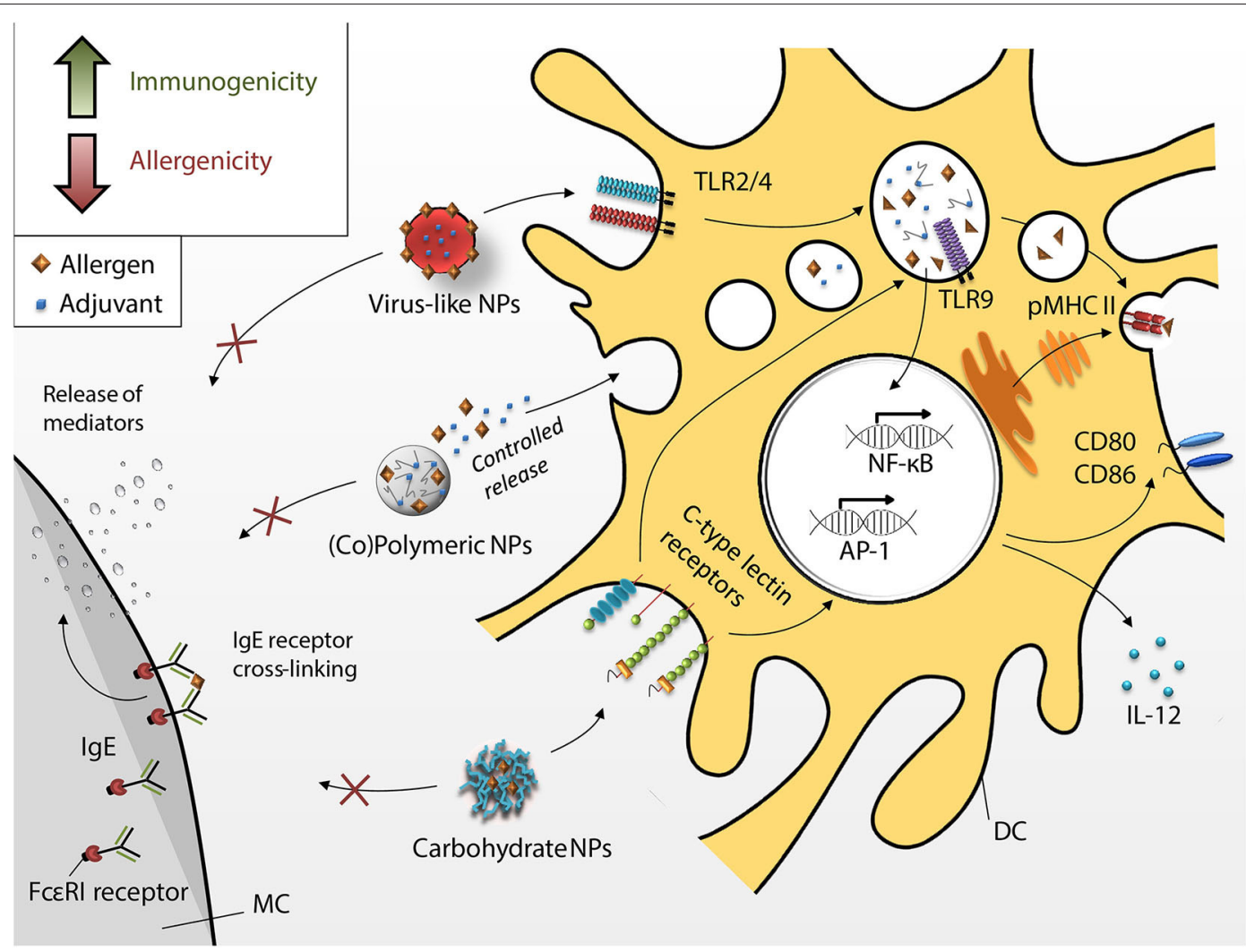

FIGURE 4 | Dendritic cell-targeting by different nanoparticles. Novel approaches intend to increase immunogenicity (green arrow in box) and decrease allergenicity (red arrow in box) of the nano-fromulated vaccines (i.e., virus-like NPs, copolymer, and peptide-based polymeric NPs and carbohydrate NPs) taken up by DCs through receptor-mediated phagocytosis. Allergen encapsulation and increased uptake shall render vaccines hypoallergenic (i.e., inhibition of MC degranulation, red arrow in box) and more immunogenic (green arrow in box), hence, improving the overall efficacy of AIT.

Chitosan NPs have been shown to induce Th1 responses when administered via different routes. In prophylactic mouse experiments, oral immunizations with chitosan and plasmid DNA encoding the allergen induced a Th1 response and protected from subsequent allergen challenge. Chitosan particles mainly accumulated in Peyer's patches and likely were taken up by $\mathrm{M}$ cells $(232,233)$. Intranasal and oral therapeutic administrations of allergen-chitosan particles furthermore improved lung function in sensitized mice $(201,234)$. Similarly, sublingual allergen-maltodextrin formulations reduced AHR and Th2 responses in OVA-allergic mice (235). The authors suggest that oral Langerhans-like dendritic cells internalize the modified allergen and subsequently prime $\mathrm{T}$ lymphocytes in cervical lymph nodes.

Allergen neoglycoconjugates containing mannan were found to render the vaccine hypoallergenic, and to induce mixed Th1/17 immune responses after epicutaneous immunization. Bet $\mathrm{v} 1$ neoglycoconjugates were tested in human skin explants and preferentially activated $\mathrm{CD} 14^{+}, \mathrm{CD}_{1} 4^{+} \mathrm{CD} \mathrm{a}^{+}$and $\mathrm{CD} 14^{-}$ $\mathrm{CD} 1 \mathrm{a}^{-}$DC subsets as well as Langerhans cells. As CD14 ${ }^{+}$ DCs overexpress mannose receptor, conjugates were most likely internalized via this C-type lectin receptor. Additionally, Bet v 1-mannan activated complement, which can enhance uptake via complement receptors (236). Animals treated intradermally with the mannan-modified allergen papain displayed significantly higher antigen-specific IgG titers in sera and showed the lowest induction of IgE responses compared to unconjugated allergen. MHC $\mathrm{II}^{\text {high }} \mathrm{CD} 8 \alpha^{+}$DCs were efficiently targeted by these conjugates (237). Mannose glycodendropeptide nanostructures conjugated with Pru p 3 peptide protected sensitized mice from anaphylactic shock after sublingual applications (238). The protection was provided due to a decreased Th2 and increased Th1/Treg responses. Subcutaneous injections of allergoidmannan conjugates for the treatment of canine atopic dermatitis resulted in a clear clinical improvement of the disease. The conjugates were shown to be internalized by human monocytederived dendritic cells via C-type lectin receptors $(239,240)$. Mannan neoglycoconjugates and allergoids of grass pollen and mites are currently in phase II clinical trials of sublingual and subcutaneous immunotherapy (241).

\section{Copolymer Nanoparticles}

Encapsulating allergen in biodegradable polymeric NPs provides a better safety profile during immunizations and activates the uptake by APCs, thus enhancing cellular and humoral responses (242). Poly(lactic-co-glycolic acid) (PLGA)-based drugs are 
approved by the FDA and the European Medical Agency for subcutaneous, intramuscular and oral administration. In a model of murine allergic rhinitis induced by the pollen allergen Che a 3 , animals were treated with recombinant Che a 3 incorporated into PLGA NPs $(243,244)$. In both studies, sublingual AIT with PLGA NPs resulted in the eradication of allergic rhinitis symptoms and induced Th1/Treg responses. Liu et al. (245) targeted liver sinusoidal endothelial cells with surface-modified PLGA NPs to induce tolerance against ovalbumin in a murine asthma model. In a murine cow's milk allergy model, prophylactic oral applications of beta-lactoglobulin-derived peptides incorporated into PLGA NPs induced tolerance to the whole whey protein after sensitization (242). In SLIT nanoparticles are captured within sublingual mucosa by Langerhans-like dendritic cells (246) and swallowed allergen is later taken up by M cells in Peyer's patches (244).

Polyanhydride is a copolymer of methyl vinyl and maleic anhydride (PVMA) and it is marketed as Gantrez ${ }^{\circledR}$. The material is biocompatible and provides sustained release (247). When used in oral administrations, it can protect the allergen from enzymatic degradation and prolong the duration of allergen contact with the mucosa (199). Furthermore, PVMA carriers have been shown to target TLR2- and TLR4-inducing DC maturation and Th1 induction (248). In two recent studies, sensitized mice were treated with peanut extract encapsulated in Gantrez ${ }^{\circledR}$ NPs $(199,249)$. Treated mice displayed higher survival rates after allergen challenge compared to nontreated and allergen extract-treated groups. Another nut-related allergy study used cashew allergen-loaded polyanhydride NPs for oral immunizations. After a single dose, NPs induced a higher Th1/Th2 ratio and increased Treg cell count. Likely, polyanhydride nanoparticles interacted with immune cells within Peyer's patches (249).

\section{Peptide-Based Polymeric Nanoparticles}

$\gamma$-PGA is a bacterial exopolymer, which is used with Lphenylalanine ethylester to generate self-assembling NPs. The carriers are biodegradable and due to their nature, directly target DCs and induce APC maturation. After i.v. injection, nanoparticle internalization was highest in $\mathrm{CD} 11 \mathrm{c}^{+}$and $\mathrm{CD} 11 \mathrm{c}^{+}$ $\mathrm{CD}^{+}$splenic DCs (250). $\gamma$-PGA NPs loaded with recombinant Phl p 5 expanded allergen-specific IL-10-producing memory $\mathrm{T}$ cells when incubated with human monocyte-derived DCs. Nanoparticles were preferentially internalized by myeloid DCs (mDCs), but not plasmacytoid DCs. TLR2 and TLR4 played an important role in the maturation of $\mathrm{mDCs}$ induced by $\gamma$ PGA NPs (251). The authors of this study suggested the use of $\gamma$-PGA NPs also for intranasal immunotherapy. However, oral administration should be considered with caution, since $\gamma$-PGAcontaining foods (e.g., fermented soybeans) may cause late-onset anaphylaxis (252).

Protamine is a $4 \mathrm{kDa}$-cationic peptide, which is commonly used to design carriers for cancer therapy $(253,254)$. PaliScholl et al. (255) used protamine NPs doped with the TLR9 ligands CpG-oligodeoxynucleotides, so-called proticles, for antiallergy immunizations. Proticles were efficiently taken up by BMDCs and activated them. In vivo, proticles formed a depot at the injection site and subcutaneous immunotherapy of peanutallergic mice resulted in a modulation of the immune responses toward Th1.

\section{Virus-Like Nanoparticles}

Virus-like nanoparticles (VLP) are derived from viral capsid proteins and are often used for allergen-specific immunotherapy in conjunction with adjuvants such as CpG oligodeoxynucleotides (256), or more recently, tetanus epitopes (257). A series of clinical studies with allergen extracts and CpG oligodeoxynucleotides in bacteriophage Q $\beta$ G10 coat proteins (CYT003) were performed by Cytos Biotechnology (258, 259). The vaccine was well-tolerated by sensitized individuals without any severe adverse effects and alleviated allergic symptoms after 10 weeks of AIT. However, in later studies the company focused on unspecific treatment of asthma with CYT003 (without allergen extract) and failed to demonstrate efficacy in a phase II clinical trial (260). Kratzer et al. (261) delivered Art v 1 allergen packed in a VLP-envelope from Moloney murine leukemia virus (MA::Art v 1 VNP). Preventive capacity of the nanoparticles was tested in humanized mouse model of mugwort pollen allergy. After intranasal application, these VLPs targeted CD103 ${ }^{+}$DCs in lung and alveolar macrophages resulting in Th1/Treg responses that had a protective effect on subsequent sensitization with mugwort pollen extract.

\section{Inorganic Nanoparticles}

Inorganic NPs based on silicon dioxide carriers have displayed potential for AIT. They are physically and thermally stable, can have a wide range of possible chemical modifications on their surface, and can be produced in a size range of 3 to several hundred nanometers (262). Silica NPs can either have a solid core with a functionalized surface, or be mesoporous, i.e., have the ability to adsorb protein internally and may provide sustained release of the antigen (263). Mesoporous silica NPs associated with Der f 2 have been studied in a murine HDM allergy model. Subcutaneous injections have shown a preventive effect with a decreased Th2 response and boosted Th1 immunity with elevated allergen-specific IgG levels (264). However, safety of inorganic nanoparticles is still under debate and this may prevent implementation of this method in the clinic (265).

\section{Clinical Outlook}

Chitosan, $\gamma$-PGA nanoparticles and proticles were successfully tested in animal models, but no new studies have been published in the last 7 years. PLGA- and PVMA-based allergen-specific immunotherapy has shown positive results in pre-clinical animal models in the last 2 years. However, no data on ongoing clinical studies is available. Two types of nanoparticles which made their way to the clinics are mannan conjugates and VLPs. Clinical trials with empty VLPs did not show any efficacy and were discontinued. New types of VLPs, MA::Art v 1, have not been tested in the clinics yet.

Subcutaneous and sublingual administration of hypoallergenic mannan glycoconjugates were efficient in animal models of allergic sensitization and currently are in phase 2 clinical trials (241). Preclinical studies with carbohydrate 
nanoparticles have shown that this approach can be further improved by the use of skin as immunization site. In contrast to hypodermis, where subcutaneous vaccinations are performed, epidermis and dermis are rich in APCs. I.d. injection or epicutaneous application via laser-generated micropores (189) allows direct activation of dermal DCs by nanoparticles (237). The synergy of particulate allergen conjugates targeting C-type lectin receptors on dermal DCs with delivery to superficial skin layers (236) may greatly improve existing approaches of AIT. Additionally, substitution of s.c. injections with epicutaneous application and shorter treatment protocols may improve patient compliance for anti-allergic immunizations.

\section{CONCLUDING REMARKS}

Much has been learned about the properties of individual allergens and about general factors that are associated with increased prevalence of allergic diseases. Still, it is not understood why a particular person develops sensitivity against a specific allergen. Allergy is a multifactorial disease and its induction involves bystander factors, among which particles play an important role: They promote uptake into cells, can carry

\section{REFERENCES}

1. Pawankar R. Allergic diseases and asthma: a global public health concern and a call to action. World Allergy Organ J. (2014) 7:12. doi: $10.1186 / 1939-4551-7-12$

2. Bauchau V, Durham S. Prevalence and rate of diagnosis of allergic rhinitis in Europe. Eur Respir J. (2004) 24:758-64. doi: 10.1183/09031936.04.00013904

3. Simons FER. Learning impairment and allergic rhinitis. In: Allergy and Asthma Proceedings. OceanSide Publications. (1996). p. 185-89. doi: 10.2500/108854196778996895

4. Cockburn IM, Bailit HL, Berndt ER, Finkelstein SN. Loss of work productivity due to illness and medical treatment. J Occup Environ Med. (1999) 41:948-53. doi: 10.1097/00043764-199911000-00005

5. Sullivan PW, Ghushchyan VH, Slejko JF, Belozeroff V, Globe DR, Lin SL. The burden of adult asthma in the United States: evidence from the Medical Expenditure Panel Survey. J Allergy Clin Immunol. (2011) 127:3639. e3. doi: 10.1016/j.jaci.2010.10.042

6. Akdis C, Agache I. Global atlas of allergy. Eur Acad Allergy Clin Immunol. (2014) 406. Available online at: https://www.zora.uzh.ch/id/eprint/140934/ 1/GlobalAtlasAllergy.pdf

7. Teaoaaci E. Advocacy Manifesto - Teckling the Allergy Crisis in Europe Concerted Policy Action Needed. Belgium: EAACI in Brussels (2015).

8. Melén E, Nyberg F, Lindgren CM, Berglind N, Zucchelli M, Nordling E, et al. Interactions between glutathione S-transferase P1, tumor necrosis factor, and traffic-related air pollution for development of childhood allergic disease. Environ Health Perspect. (2008) 116:1077-84. doi: 10.1289/ehp.11117

9. Platts-Mills TA. The allergy epidemics: 1870-2010. J Allergy Clin Immunol. (2015) 136:3-13. doi: 10.1016/j.jaci.2015.03.048

10. D'amato G, Pawankar R, Vitale C, Lanza M, Molino A, Stanziola A, et al. Climate change and air pollution: effects on respiratory allergy. Allergy Asthma Immunol Res. (2016) 8:391-5. doi: 10.4168/aair.2016.8.5.391

11. Platts-Mills TA, Woodfolk JA. Allergens and their role in the allergic immune response. Immunol Rev. (2011) 242:5168. doi: 10.1111/j.1600-065X.2011.01021.x

12. Abbas AK, Lichtman AH, Pillai S. Cellular and Molecular Immunology. 7th ed. Philadelphia, PA: Elsevier Saunders (2012).

13. Hamilton RG, Oppenheimer J. Serological IgE analyses in the diagnostic algorithm for allergic disease. J Allergy Clin Immunol. (2015) 3:83340. doi: 10.1016/j.jaip.2015.08.016 a multitude of chemicals as cargo and offer a platform to achieve high local concentrations of effectors. Understanding the complex interplay between particles and allergens will be essential for fully elucidating the genesis of allergy as well as for developing new generations of therapeutics.

\section{AUTHOR CONTRIBUTIONS}

All authors were involved in concept drafting, literature screening, design of display items, writing, and editing of the article.

\section{FUNDING}

The authors gratefully acknowledge financial support by the International $\mathrm{PhD}$ Program Immunity in Cancer and Allergy of the Austrian Science Fund (FWF, Grant No: W01213), the Sparkling Science project Nan-O-Style (BMBWF, SPA06/270), the European Community's Horizon 2020 Framework Program under grant agreement No: 671881 (PANDORA), and the PLUS Allergy-Cancer-BioNano (ACBN) Research Center.

14. Molinari G, Colombo G, Celenza C. Respiratory allergies: a general overview of remedies, delivery systems, and the need to progress. ISRN Allergy. (2014) 2014:326980. doi: 10.1155/2014/326980

15. Alesina R, Milani M, Pecora S. A multicenter, randomized, parallel-group trial assessing compliance, tolerability, safety, and efficacy to treatment with grass allergy tablets in 261 patients with grass pollen rhinoconjunctivitis. $J$ Allergy. (2012) 2012:673502. doi: 10.1155/2012/673502

16. Sohn MH. Efficacy and safety of subcutaneous allergen immunotherapy for allergic rhinitis. Allergy Asthma Immunol Res. (2018) 10:1-3. doi: 10.4168/aair.2018.10.1.1

17. Biedermann T, Winther L, Till SJ, Panzner P, Knulst A, Valovirta E. Birch pollen allergy in Europe. Allergy. (2019) 74:1237-48. doi: 10.1111/all. 13758

18. Beck I, Jochner S, Gilles S, McIntyre M, Buters JT, Schmidt-Weber C, et al. High environmental ozone levels lead to enhanced allergenicity of birch pollen. PLoS ONE. (2013) 8:e80147. doi: 10.1371/journal.pone.0080147

19. Phosri A, Ueda K, Tasmin S, Kishikawa R, Hayashi M, Hara K, et al. Interactive effects of specific fine particulate matter compositions and airborne pollen on frequency of clinic visits for pollinosis in Fukuoka, Japan. Environ Res. (2017) 156:411-9. doi: 10.1016/j.envres.2017.04.008

20. Pablos I, Wildner S, Asam C, Wallner M, Gadermaier G. Pollen allergens for molecular diagnosis. Curr Allergy Asthma Rep. (2016) 16:31. doi: 10.1007/s11882-016-0603-Z

21. Chan SK, Pomés A, Hilger C, Davies JM, Mueller G, Kuehn A, et al. Keeping allergen names clear and defined. Front Immunol. (2019) 10:2600. doi: 10.3389/fimmu.2019.02600

22. Arbes SJ Jr, Cohn RD, Yin M, Muilenberg ML, Friedman W, Zeldin DC. Dog allergen (Can f 1) and cat allergen (Fel d 1) in US homes: results from the National Survey of Lead and Allergens in Housing. J Allergy Clin Immunol. (2004) 114:111-7. doi: 10.1016/j.jaci.2004.04.036

23. Salo PM, Arbes SJ Jr, Crockett PW, Thorne PS, Cohn RD, Zeldin DC. Exposure to multiple indoor allergens in US homes and its relationship to asthma. J Allergy Clin Immunol. (2008) 121:678-84.e2. doi: 10.1016/j.jaci.2007.12.1164

24. Stemeseder T, Schweidler B, Doppler P, Klinglmayr E, Moser S, Lueftenegger $\mathrm{L}$, et al. Exposure to indoor allergens in different residential settings and its influence on IgE sensitization in a geographically confined Austrian cohort. PLoS ONE. (2017) 12:e0168686. doi: 10.1371/journal.pone. 0168686 
25. D'amato G, Spieksma FT. Aerobiologic and clinical aspects of mould allergy in Europe. Allergy. (1995) 50:870-7. doi: 10.1111/j.1398-9995.1995.tb02492.x

26. Hamilton ED. Pollen and fungus spore counts. Proc R Soc Med. (1963) 56:220-1. doi: 10.1177/003591576305600329

27. Matricardi P, Kleine-Tebbe J, Hoffmann H, Valenta R, Hilger C, Hofmaier $\mathrm{S}$, et al. EAACI molecular allergology user's guide. Pediatr Allergy Immunol. (2016) 27:1-250. doi: 10.1111/pai.2016.27.issue-S23

28. Valenta R, Karaulov A, Niederberger V, Zhernov Y, Elisyutina O, Campana $\mathrm{R}$, et al. Allergen extracts for in vivo diagnosis and treatment of allergy: is there a future? J Allergy Clin Immunol. (2018) 6:184555.e2. doi: 10.1016/j.jaip.2018.08.032

29. Jutel M, Rudert M, Kreimendahl F, Kuna P. Efficacy and tolerability of a house dust mite allergoid in allergic bronchial asthma: a randomized dose-ranging trial. Immunotherapy. (2018) 10:1149-61. doi: 10.2217/imt-2018-0087

30. Miller JD. The role of dust mites in allergy. Clin Rev Allergy Immunol. (2019) 57:312-29. doi: 10.1007/s12016-018-8693-0

31. Oteros J, Bartusel E, Alessandrini F, Núñez A, Moreno DA, Behrendt H, et al. Artemisia pollen is the main vector for airborne endotoxin. J Allergy Clin Immunol. (2019) 143:369-77.e5. doi: 10.1016/j.jaci.2018.05.040

32. Woodfolk JA, Commins SP, Schuyler AJ, Erwin EA, Platts-Mills TA. Allergens, sources, particles, and molecules: why do we make IgE responses? Allergol Int. (2015) 64:295-303. doi: 10.1016/j.alit.2015.06.001

33. Bush RK, Wood RA, Eggleston PA. Laboratory animal allergy. J Allergy Clin Immunol. (1998) 102:99-112. doi: 10.1016/S0091-6749(98)70060-0

34. De Blay F, Heymann PW, Chapman MD, Platts-Mills TA. Airborne dust mite allergens: comparison of group II allergens with group I mite allergen and cat-allergen Feld I. J Allergy Clin Immunol. (1991) 88:91926. doi: 10.1016/0091-6749(91)90249-N

35. Anderson M, Baer H, Ohman JL Jr. A comparative study of the allergens of cat urine, serum, saliva, and pelt. J Allergy Clin Immunol. (1985) 76:5639. doi: 10.1016/0091-6749(85)90776-6

36. Portnoy JM, Kennedy K, Sublett JL, Phipatanakul W, Matsui E, Barnes C, et al. Environmental assessment and exposure control: a practice parameter-furry animals. Ann Allergy Asthma Immunol. (2012) 108:223.e1-5. doi: 10.1016/j.anai.2012.02.015

37. Charpin C, Mata P, Charpin D, Lavaut M, Allasia C, Vervloet D. Feld I allergen distribution in cat fur and skin. J Allergy Clin Immunol. (1991) 88:77-82. doi: 10.1016/0091-6749(91)90303-6

38. Zahradnik E, Raulf M. Animal allergens and their presence in the environment. Front Immunol. (2014) 5:76. doi: 10.3389/fimmu.2014.00076

39. De Lucca S, Sporik R, O’Meara TJ, Tovey ER. Mite allergen (Der p 1) is not only carried on mite feces. J Allergy Clin Immunol. (1999) 103:1745. doi: 10.1016/S0091-6749(99)70543-9

40. Fröhlich-Nowoisky J, Pickersgill DA, Després VR, Pöschl U. High diversity of fungi in air particulate matter. Proc Natl Acad Sci USA. (2009) 106:128149. doi: 10.1073/pnas.0811003106

41. Erdtman G. Pollen morphology and plant taxonomy ILabiatae V, Verbenaceae and Avicenniaceae. Svenk Bot Tidskr. (1945) 39:279-85.

42. Schäppi GF, Taylor PE, Pain MC, Cameron PA, Dent A, Staff IA, et al. Concentrations of major grass group 5 allergens in pollen grains and atmospheric particles: implications for hay fever and allergic asthma sufferers sensitized to grass pollen allergens. Clin Exp Allergy. (1999) 29:63341. doi: 10.1046/j.1365-2222.1999.00567.x

43. Lewis S, Corden J, Forster G, Newlands M. Combined effects of aerobiological pollutants, chemical pollutants and meteorological conditions on asthma admissions and A \& E attendances in Derbyshire UK, 199396. Clin Exp Allergy. (2000) 30:1724-32. doi: 10.1046/j.1365-2222.2000. 00947.x

44. Schäppi GF, Suphioglu C, Taylor PE, Knox RB. Concentrations of the major birch tree allergen Bet $\mathrm{v} 1$ in pollen and respirable fine particles in the atmosphere. J Allergy Clin Immunol. (1997) 100:65661. doi: 10.1016/S0091-6749(97)70170-2

45. Smiljanic K, Apostolovic D, Trifunovic S, Ognjenovic J, Perusko M, Mihajlovic L, et al. Subpollen particles are rich carriers of major short ragweed allergens and $\mathrm{NADH}$ dehydrogenases: quantitative proteomic and allergomic study. Clin Exp Allergy. (2017) 47:815-28. doi: 10.1111/cea. 12874
46. Pope III CA, Dockery DW. Acute health effects of PM10 pollution on symptomatic and asymptomatic children. Am Rev Respir Dis. (1992) 145:1123-8. doi: 10.1164/ajrccm/145.5.1123

47. Dockery DW, Pope CA. Acute respiratory effects of particulate air pollution. Ann Rev Public Health. (1994) 15:10732. doi: 10.1146/annurev.pu.15.050194.000543

48. Kalic T, Ellinger I, Kamath SD, Palladino C, Mayr V, Tscheppe A, et al. Fish-derived low molecular weight components modify bronchial epithelial barrier properties and release of pro-inflammatory cytokines. Mol Immunol. (2019) 112:140-50. doi: 10.1016/j.molimm.2019.04.029

49. Knox R, Suphioglu C, Taylor P, Desai R, Watson HC, Peng JL, et al. Major grass pollen allergen Lol p 1 binds to diesel exhaust particles: implications for asthma and air pollution. Clin Exp Allergy. (1997) 27:24651. doi: 10.1046/j.1365-2222.1997.d01-508.x

50. Ormstad H. Suspended particulate matter in indoor air: adjuvants and allergen carriers. Toxicology. (2000) 152:5368. doi: 10.1016/S0300-483X(00)00292-4

51. Namork E, Johansen BV, Løvik M. Detection of allergens adsorbed to ambient air particles collected in four European cities. Toxicol Lett. (2006) 165:71-8. doi: 10.1016/j.toxlet.2006.01.016

52. Gowers AM, Cullinan P, Ayres JG, Anderson HR, Strachan DP, Holgate ST, et al. Does outdoor air pollution induce new cases of asthma? biological plausibility and evidence; a review. Respirology. (2012) 17:88798. doi: 10.1111/j.1440-1843.2012.02195.x

53. Li N, Georas S, Alexis N, Fritz P, Xia T, Williams MA, et al. A work group report on ultrafine particles (American Academy of Allergy, Asthma \& Immunology): why ambient ultrafine and engineered nanoparticles should receive special attention for possible adverse health outcomes in human subjects. J Allergy Clin Immunol. (2016) 138:38696. doi: 10.1016/j.jaci.2016.02.023

54. Hosseini A, Hirota JA, Hackett TL, McNagny KM, Wilson SJ, Carlsten C. Morphometric analysis of inflammation in bronchial biopsies following exposure to inhaled diesel exhaust and allergen challenge in atopic subjects. Particle Fibre Toxicol. (2015) 13:2. doi: 10.1186/s12989-016-0114-Z

55. Behrendt H, Alessandrini F, Buters J, Krämer U, Koren H, Ring J. Environmental pollution and allergy: historical aspects, in History of Allergy. Chem Immunol Allergy. (2014) 100:268-77. doi: 10.1159/000359918

56. Wu W, Jin Y, Carlsten C. Inflammatory health effects of indoor and outdoor particulate matter. J Allergy Clin Immunol. (2018) 141:83344. doi: 10.1016/j.jaci.2017.12.981

57. Baldacci S, Maio S, Cerrai S, Sarno G, Baiz N, Simoni M, et al. Allergy and asthma: effects of the exposure to particulate matter and biological allergens. Respir Med. (2015) 109:1089-104. doi: 10.1016/j.rmed.2015.05.017

58. Gold MJ, Hiebert PR, Park HY, Stefanowicz D, Le A, Starkey MR, et al. Mucosal production of uric acid by airway epithelial cells contributes to particulate matter-induced allergic sensitization. Mucosal Immunol. (2016) 9:809-20. doi: 10.1038/mi.2015.104

59. Bowatte G, Lodge C, Lowe AJ, Erbas B, Perret J, Abramson MJ, et al. The influence of childhood traffic-related air pollution exposure on asthma, allergy and sensitization: a systematic review and a meta-analysis of birth cohort studies. Allergy. (2015) 70:245-56. doi: 10.1111/all.12561

60. Castaneda AR, Bein KJ, Smiley-Jewell S, Pinkerton KE. Fine particulate matter (PM2.5) enhances allergic sensitization in BALB/c mice. J Toxicol Environ Health A. (2017) 80:197-207. doi: 10.1080/15287394.2016.1222920

61. Yang SI. Particulate matter and childhood allergic diseases. Korean J Pediatr. (2019) 62:22-9. doi: 10.3345/kjp.2018.07045

62. Kim KH, Kabir E, Kabir S. A review on the human health impact of airborne particulate matter. Environ Int. (2015) 74:136-43. doi: 10.1016/j.envint.2014.10.005

63. Gilli G, Traversi D, Rovere R, Pignata C, Schilirò T. Chemical characteristics and mutagenic activity of PM10 in Torino, a Northern Italian City. Sci Total Environ. (2007) 385:97-107. doi: 10.1016/j.scitotenv.2007.07.006

64. Kadiiska MB, Mason RP, Dreher $\mathrm{KL}$, Costa $\mathrm{DL}$, Ghio $\mathrm{AJ}$. In vivo evidence of free radical formation in the rat lung after exposure to an emission source air pollution particle. Chem Res Toxicol. (1997) 10:11048. doi: 10.1021/tx970049r

65. Pirie R, Collie D, Dixon P, McGorum B. Inhaled endotoxin and organic dust particulates have synergistic proinflammatory effects in equine 
heaves (organic dust-induced asthma). Clin Exp Allergy. (2003) 33:67683. doi: 10.1046/j.1365-2222.2003.01640.x

66. DiazSanchez D. The role of diesel exhaust particles and their associated polyaromatic hydrocarbons in the induction of allergic airway disease. Allergy. (1997) 52:52-6. doi: 10.1111/j.1398-9995.1997.tb04871.x

67. De Grove K, Provoost S, Brusselle G, Joos G, Maes T. Insights in particulate matter-induced allergic airway inflammation: focus on the epithelium. Clin Exp Allergy. (2018) 48:773-86. doi: 10.1111/cea.13178

68. Senechal H, Visez N, Charpin D, Shahali Y, Peltre G, Biolley JP, et al. A review of the effects of major atmospheric pollutants on pollen grains, pollen content, and allergenicity. Sci World J. (2015) 2015:940243. doi: 10.1155/2015/940243

69. Ribeiro H, Guimaraes F, Duque L, Noronha F, Abreu I. Characterisation of particulate matter on airborne pollen grains. Environ Pollut. (2015) 206:7-16. doi: 10.1016/j.envpol.2015.06.015

70. Lubitz S, Schober W, Pusch G, Effner R, Klopp N, Behrendt H, et al. Polycyclic aromatic hydrocarbons from diesel emissions exert proallergic effects in birch pollen allergic individuals through enhanced mediator release from basophils. Environ Toxicol. (2010) 25:188-97. doi: 10.1002/tox.20490

71. Fukuoka A, Matsushita K, Morikawa T, Takano H, Yoshimoto T. Diesel exhaust particles exacerbate allergic rhinitis in mice by disrupting the nasal epithelial barrier. Clin Exp Allergy. (2016) 46:142-52. doi: 10.1111/cea.12597

72. Gehring U, Beelen R, Eeftens M, Hoek G, De Hoogh K, De Jongste JC, et al. Particulate matter composition and respiratory health: the PIAMA Birth Cohort study. Epidemiology. (2015) 26:300-9. doi: 10.1097/EDE.0000000000000264

73. Richardson G, Eick S, Jones R. How is the indoor environment related to asthma?: literature review. J Adv Nurs. (2005) 52:32839. doi: 10.1111/j.1365-2648.2005.03591.x

74. Becquemin M, Bertholon J, Attoui M, Roy F, Roy M, Dautzenberg B. Particle size in the smoke produced by six different types of cigarette. Rev Mal Respir. (2007) 24:845-52. doi: 10.1016/S0761-8425(07)91386-8

75. Schwartz AG, Cote ML. Epidemiology of Lung Cancer. Adv Exp Med Biol. (2016) 893:21-41. doi: 10.1007/978-3-319-24223-1_2

76. Feleszko W, Ruszczynski M, Jaworska J, Strzelak A, Zalewski BM, Kulus M. Environmental tobacco smoke exposure and risk of allergic sensitisation in children: a systematic review and meta-analysis. Arch Dis Child. (2014) 99:985-92. doi: 10.1136/archdischild-2013-305444

77. Thacher JD, Gruzieva O, Pershagen G, Neuman A, van Hage M, Wickman $\mathrm{M}$, et al. Parental smoking and development of allergic sensitization from birth to adolescence. Allergy. (2016) 71:239-48. doi: 10.1111/all.12792

78. Shargorodsky J, Garcia-Esquinas E, Galan I, Navas-Acien A, Lin SY. Allergic sensitization, rhinitis and tobacco smoke exposure in US adults. PLoS ONE. (2015) 10:e0131957. doi: 10.1371/journal.pone.0131957

79. Shargorodsky J, Garcia-Esquinas E, Navas-Acien A, Lin SY. Allergic sensitization, rhinitis, and tobacco smoke exposure in US children and adolescents. Int Forum Allergy Rhinol. (2015) 5:471-6. doi: 10.1002/alr.21444

80. Maes T, Provoost S, Lanckacker EA, Cataldo DD, Vanoirbeek JA, Nemery $\mathrm{B}$, et al. Mouse models to unravel the role of inhaled pollutants on allergic sensitization and airway inflammation. Respir Res. (2010) 11:7. doi: 10.1186/1465-9921-11-7

81. Acciani TH, Brandt EB, Khurana Hershey GK, Le Cras TD. Diesel exhaust particle exposure increases severity of allergic asthma in young mice. Clin Exp Allergy. (2013) 43:1406-18. doi: 10.1111/cea.12200

82. Brandt EB, Biagini Myers JM, Acciani TH, Ryan PH, Sivaprasad U, Ruff B, et al. Exposure to allergen and diesel exhaust particles potentiates secondary allergen-specific memory responses, promoting asthma susceptibility. $J$ Allergy Clin Immunol. (2015) 136:295-303.e7. doi: 10.1016/j.jaci.2014. 11.043

83. Castaneda AR, C.Vogel FA, Bein KJ, Hughes HK, Smiley-Jewell S, Pinkerton KE. Ambient particulate matter enhances the pulmonary allergic immune response to house dust mite in a BALB/c mouse model by augmenting Th2- and Th17-immune responses. Physiol Rep. (2018) 6:e13827. doi: 10.14814/phy2.13827

84. Aglas L, Gilles S, Bauer R, Huber S, Araujo GR, Mueller G, et al. Context matters: TH2 polarization resulting from pollen composition and not from protein-intrinsic allergenicity. J Allergy Clin Immunol. (2018) 142:9847.e6. doi: 10.1016/j.jaci.2018.05.004
85. Strasser L, Dang HH, Schwarz H, Asam C, Ferreira F, Horejs-Hoeck $\mathrm{J}$, et al. Unbiased quantitative proteomics reveals a crucial role of the allergen context for the activation of human dendritic cells. Sci Rep. (2017) 7:16638. doi: 10.1038/s41598-017-16726-2

86. de Jong EC, Smits HH, Kapsenberg ML. Dendritic cell-mediated $\mathrm{T}$ cell polarization. Springer Semin Immunopathol. (2005) 26:289-307. doi: 10.1007/s00281-004-0167-1

87. Kumamoto Y, Linehan M, Weinstein JS, Laidlaw BJ, Craft JE, Iwasaki A. $\mathrm{CD} 301 \mathrm{~b}(+)$ dermal dendritic cells drive T helper 2 cell-mediated immunity. Immunity. (2013) 39:733-43. doi: 10.1016/j.immuni.2013.08.029

88. Radtke F, MacDonald HR, Tacchini-Cottier F. Regulation of innate and adaptive immunity by Notch. Nat Rev Immunol. (2013) 13:42737. doi: $10.1038 / \mathrm{nri} 3445$

89. Webb GJ, Hirschfield GM, Lane PJ. OX40, OX40L and autoimmunity: a comprehensive review. Clin Rev Allergy Immunol. (2016) 50:31232. doi: $10.1007 /$ s12016-015-8498-3

90. Walker JA, A.McKenzie NJ. TH2 cell development and function. Nat Rev Immunol. (2018) 18:121-33. doi: 10.1038/nri.2017.118

91. Xia M, Harb H, Saffari A, Sioutas C, Chatila TA. A Jagged 1-Notch 4 molecular switch mediates airway inflammation induced by ultrafine particles. J Allergy Clin Immunol. (2018) 142:1243-56.e17. doi: 10.1016/j.jaci.2018.03.009

92. Amsen D, Antov A, Jankovic D, Sher A, Radtke F, Souabni A, et al. Direct regulation of Gata3 expression determines the $\mathrm{T}$ helper differentiation potential of Notch. Immunity. (2007) 27:89-99. doi: 10.1016/j.immuni.2007.05.021

93. Fang TC, Yashiro-Ohtani Y, Del Bianco C, Knoblock DM, Blacklow SC, Pear WS. Notch directly regulates Gata3 expression during $\mathrm{T}$ helper 2 cell differentiation. Immunity. (2007) 27:100-10. doi: 10.1016/j.immuni.2007.04.018

94. Xia M, Viera-Hutchins L, Garcia-Lloret M, Noval Rivas M, Wise P, McGhee $\mathrm{SA}$, et al. Vehicular exhaust particles promote allergic airway inflammation through an aryl hydrocarbon receptor-notch signaling cascade. J Allergy Clin Immunol. (2015) 136:441-53. doi: 10.1016/j.jaci.2015.02.014

95. Gao Y, Nish SA, Jiang R, Hou L, Licona-Limon P, Weinstein JS, et al. Control of $\mathrm{T}$ helper 2 responses by transcription factor IRF4-dependent dendritic cells. Immunity. (2013) 39:722-32. doi: 10.1016/j.immuni.2013.08.028

96. Williams JW, Tjota MY, Clay BS, Vander Lugt B, Bandukwala HS, Hrusch $\mathrm{CL}$, et al. Transcription factor IRF4 drives dendritic cells to promote Th2 differentiation. Nat Commun. (2013) 4:2990. doi: 10.1038/ncomms3990

97. Tussiwand R, Everts B, Grajales-Reyes GE, Kretzer NM, Iwata A, Bagaitkar J, et al. Klf4 expression in conventional dendritic cells is required for $\mathrm{T}$ helper 2 cell responses. Immunity. (2015) 42:91628. doi: 10.1016/j.immuni.2015.04.017

98. Hammad H, Chieppa M, Perros F, Willart MA, Germain RN, Lambrecht BN. House dust mite allergen induces asthma via Toll-like receptor 4 triggering of airway structural cells. Nat Med. (2009) 15:410-6. doi: 10.1038/nm.1946

99. Divekar R, Kita H. Recent advances in epithelium-derived cytokines (IL-33, IL-25, and thymic stromal lymphopoietin) and allergic inflammation. Curr Opin Allergy Clin Immunol. (2015) 15:98-103. doi: 10.1097/ACI.0000000000000133

100. Schmitz J, Owyang A, Oldham E, Song Y, Murphy E, McClanahan TK, et al. IL-33, an interleukin-1-like cytokine that signals via the IL-1 receptor-related protein ST2 and induces T helper type 2-associated cytokines. Immunity. (2005) 23:479-90. doi: 10.1016/j.immuni.2005.09.015

101. van Dyken SJ, Nussbaum JC, Lee J, Molofsky AB, Liang HE, Pollack JL, et al. A tissue checkpoint regulates type 2 immunity. Nat Immunol. (2016) 17:1381-87. doi: 10.1038/ni.3582

102. Sokol CL, Chu NQ, Yu S, Nish SA, Laufer TM, Medzhitov R. Basophils function as antigen-presenting cells for an allergen-induced $\mathrm{T}$ helper type 2 response. Nat Immunol. (2009) 10:713-20. doi: 10.1038/ni.1738

103. Eckl-Dorna J, Ellinger A, Blatt K, Ghanim V, Steiner I, Pavelka M, et al. Basophils are not the key antigen-presenting cells in allergic patients. Allergy. (2012) 67:601-8. doi: 10.1111/j.1398-9995.2012.02792.x

104. Kitzmuller C, Nagl B, Deifl S, Walterskirchen C, Jahn-Schmid B, Zlabinger GJ, et al. Human blood basophils do not act as antigen-presenting cells for the major birch pollen allergen Bet v 1. Allergy. (2012) 67:593600. doi: 10.1111/j.1398-9995.2011.02764.x 
105. Hammad H, Plantinga M, Deswarte K, Pouliot P, Willart MA, Kool M, et al. Inflammatory dendritic cells-not basophils-are necessary and sufficient for induction of Th2 immunity to inhaled house dust mite allergen. J Exp Med. (2010) 207:2097-111. doi: 10.1084/jem.20101563

106. Miyake K, Shiozawa N, Nagao T, Yoshikawa S, Yamanishi Y, Karasuyama H. Trogocytosis of peptide-MHC class II complexes from dendritic cells confers antigen-presenting ability on basophils. Proc Natl Acad Sci USA. (2017) 114:1111-6. doi: 10.1073/pnas.1615973114

107. Vivier E, Artis D, Colonna M, Diefenbach A, Di Santo JP, Eberl G, et al. Innate lymphoid cells: 10 years on. Cell. (2018) 174:105466. doi: 10.1016/j.cell.2018.07.017

108. Hoyler T, Klose CS, Souabni A, Turqueti-Neves A, Pfeifer D, Rawlins EL, et al. The transcription factor GATA-3 controls cell fate and maintenance of type 2 innate lymphoid cells. Immunity. (2012) 37:63448. doi: 10.1016/j.immuni.2012.06.020

109. Moro K, Yamada $T$, Tanabe $M$, Takeuchi $T$, Ikawa $T$, Kawamoto $\mathrm{H}$, et al. Innate production of $\mathrm{T}(\mathrm{H}) 2$ cytokines by adipose tissueassociated c-Kit $(+)$ Sca-1(+) lymphoid cells. Nature. (2010) 463:5404. doi: 10.1038 /nature 08636

110. Klein Wolterink RG, Serafini N, van Nimwegen M, Vosshenrich CA, de Bruijn MJ, Fonseca Pereira D, et al. Essential, dose-dependent role for the transcription factor Gata3 in the development of IL-5+ and IL-13+ type 2 innate lymphoid cells. Proc Natl Acad Sci USA. (2013) 110:102405. doi: $10.1073 /$ pnas. 1217158110

111. Klein Wolterink RG, Kleinjan A, van Nimwegen M, Bergen I, de Bruijn M, Levani Y, et al. Pulmonary innate lymphoid cells are major producers of IL5 and IL-13 in murine models of allergic asthma. Eur J Immunol. (2012) 42:1106-16. doi: 10.1002/eji.201142018

112. Pelly VS, Kannan Y, Coomes SM, Entwistle LJ, Ruckerl D, Seddon B, et al. IL-4-producing ILC2s are required for the differentiation of TH2 cells following Heligmosomoides polygyrus infection. Mucosal Immunol. (2016) 9:1407-17. doi: $10.1038 / \mathrm{mi} .2016 .4$

113. Holgate ST. Pathogenesis of asthma. Clin Exp Allergy. (2008) 38:87297. doi: $10.1111 / \mathrm{j} .1365-2222.2008 .02971 . \mathrm{x}$

114. Hogg JC. The pathology of asthma. Apmis. (1997) 105:73545. doi: 10.1111/j.1699-0463.1997.tb05079.x

115. Bentley AM, Maestrelli P, Saetta M, Fabbri LM, Robinson DS, Bradley BL, et al. Activated T-lymphocytes and eosinophils in the bronchial mucosa in isocyanate-induced asthma. J Allergy Clin Immunol. (1992) 89:8219. doi: 10.1016/0091-6749(92)90437-7

116. Bentley A, Meng Q, Robinson D, Hamid Q, Kay A, Durham S. Increases in activated T lymphocytes, eosinophils, and cytokine mRNA expression for interleukin-5 and granulocyte/macrophage colony-stimulating factor in bronchial biopsies after allergen inhalation challenge in atopic asthmatics. Am J Respir Cell Mol Biol. (1993) 8:35. doi: 10.1165/ajrcmb/8.1.35

117. Bradley BL, Azzawi M, Jacobson M, Assoufi B, Collins JV, Anne-marie AI, et al. Eosinophils, T-lymphocytes, mast cells, neutrophils, and macrophages in bronchial biopsy specimens from atopic subjects with asthma: comparison with biopsy specimens from atopic subjects without asthma and normal control subjects and relationship to bronchial hyperresponsiveness. J Allergy Clin Immunol. (1991) 88:661-74. doi: 10.1016/0091-6749(91)90160-P

118. Van Oosterhout A, Bloksma N. Regulatory T-lymphocytes in asthma. Eur Respir J. (2005) 26:918-32. doi: 10.1183/09031936.05.000 11205

119. Umetsu DT, Akbari O, DeKruyff RH, Shearer WT, Rosenwasser LJ, Bochner BS. Regulatory $\mathrm{T}$ cells control the development of allergic disease and asthma. J Allergy Clin Immunol. (2003) 112:480-7. doi: 10.1016/S0091-6749(03)01869-4

120. Larche M. Regulatory T cells in allergy and asthma. Chest. (2007) 132:100714. doi: 10.1378/chest.06-2434

121. Illi S, Depner M, Genuneit J, Horak E, Loss G, Strunz-Lehner C, et al. Protection from childhood asthma and allergy in Alpine farm environments-the GABRIEL advanced studies. J Allergy Clin Immunol. (2012) 129:1470-7.e6. doi: 10.1016/j.jaci.2012.03.013

122. Schaub B, Liu J, Höppler S, Schleich I, Huehn J, Olek S, et al. Maternal farm exposure modulates neonatal immune mechanisms through regulatory $\mathrm{T}$ cells. J Allergy Clin Immunol. (2009) 123:774-82.e5. doi: 10.1016/j.jaci.2009.01.056
123. Maio S, Cerrai S, Simoni M, Sarno G, Baldacci S, Viegi G, et al. Environmental risk factors: indoor and outdoor pollution. WAO White Book Allergy 2011-2012. (2011) 2011:84-90. Available online at:https://www. worldallergy.org/UserFiles/file/WAO-White-Book-on-Allergy_web.pdf

124. Lee SY, Chang YS, Cho SH. Allergic diseases and air pollution. Asia Pacif Allergy. (2013) 3:145-54. doi: 10.5415/apallergy.2013.3.3.145

125. Devenny A, Wassall H, Ninan T, Omran M, Khan SD, Russell G. Respiratory symptoms and atopy in children in Aberdeen: questionnaire studies of a defined school population repeated over 35 years. BMJ. (2004) 329:48990. doi: 10.1136/bmj.38139.666447.F7

126. Kwong GNM, Proctor A, Billings C, Duggan R, Das C, Whyte $\mathrm{M}$, et al. Increasing prevalence of asthma diagnosis and symptoms in children is confined to mild symptoms. Thorax. (2001) 56:3124. doi: 10.1136/thorax.56.4.312

127. Braun-Fahrländer C, Gassner M, Grize L, Takken-Sahli K, Neu U, Stricker $\mathrm{T}$, et al. No further increase in asthma, hay fever and atopic sensitisation in adolescents living in Switzerland. Eur Respir J. (2004) 23:40713. doi: $10.1183 / 09031936.04 .00074004$

128. Zöllner I, Weiland S, Piechotowski I, Gabrio T, Von Mutius E, Link $\mathrm{B}$, et al. No increase in the prevalence of asthma, allergies, and atopic sensitisation among children in Germany: 1992-2001. Thorax. (2005) 60:545-8. doi: 10.1136/thx.2004.029561

129. Kim HY, DeKruyff RH, Umetsu DT. The many paths to asthma: phenotype shaped by innate and adaptive immunity. Nat Immunol. (2010) 11:577. doi: $10.1038 /$ ni. 1892

130. Backman H, Raisanen P, Hedman L, Stridsman C, Andersson M, Lindberg A, et al. Increased prevalence of allergic asthma from 1996 to 2006 and further to 2016-results from three population surveys. Clin Exp Allergy. (2017) 47:1426-35. doi: 10.1111/cea.12963

131. Qu J, Li Y, Zhong W, Gao P, Hu C. Recent developments in the role of reactive oxygen species in allergic asthma. J Thorac Dis. (2017) 9:E3243. doi: $10.21037 /$ jtd.2017.01.05

132. Yang J, Kim YK, Kang TS, Jee YK, Kim YY. Importance of indoor dust biological ultrafine particles in the pathogenesis of chronic inflammatory lung diseases. Environ Health Toxicol. (2017) 32:e2017021. doi: 10.5620/eht.e2017021

133. Finotto S. Resolution of allergic asthma. Semin Immunopathol. (2019) 41:665-74. doi: 10.1007/s00281-019-00770-3

134. Yen HJ, Hsu SH, Tsai CL. Cytotoxicity and immunological response of gold and silver nanoparticles of different sizes. Small. (2009) 5:155361. doi: $10.1002 /$ smll.200900126

135. Westas Janco E, Hulander M, Andersson M. Curvature-dependent effects of nanotopography on classical immune complement activation. Acta Biomaterialia. (2018) 74:112-20. doi: 10.1016/j.actbio.2018.04.053

136. Benne N, van Duijn J, Kuiper J, Jiskoot W, Slütter B. Orchestrating immune responses: how size, shape and rigidity affect the immunogenicity of particulate vaccines. J Control Release. (2016) 234:124-34. doi: 10.1016/j.jconrel.2016.05.033

137. Li Z, Sun L, Zhang Y, Dove AP, O'Reilly RK, Chen G. Shape effect of glyco-nanoparticles on macrophage cellular uptake and immune response. ACS Macro Lett. (2016) 5:1059-64. doi: 10.1021/acsmacrolett. $6 \mathrm{~b} 00419$

138. Brandenberger C, Rowley NL, Jackson-Humbles DN, Zhang Q, Bramble LA, Lewandowski RP, et al. Engineered silica nanoparticles act as adjuvants to enhance allergic airway disease in mice. Particle Fibre Toxicol. (2013) 10:26. doi: 10.1186/1743-8977-10-26

139. Yoshida T, Yoshioka Y, Fujimura M, Yamashita K, Higashisaka K, Morishita Y, et al. Promotion of allergic immune responses by intranasallyadministrated nanosilica particles in mice. Nanoscale Res Lett. (2011) 6:195. doi: 10.1186/1556-276X-6-195

140. Han H, Park YH, Park HJ, Lee K, Um K, J.-Park W, et al. Toxic and adjuvant effects of silica nanoparticles on ovalbumininduced allergic airway inflammation in mice. Respir Res. (2016) 17:60. doi: 10.1186/s12931-016-0376-x

141. Han B, Guo J, Abrahaley T, Qin L, Wang L, Zheng Y, et al Adverse effect of nano-silicon dioxide on lung function of rats with or without ovalbumin immunization. PLoS ONE. (2011) 6:e17236. doi: 10.1371/journal.pone.0017236 
142. Koike E, Takano H, Inoue KI, Yanagisawa R, Sakurai M, Aoyagi H, et al. Pulmonary exposure to carbon black nanoparticles increases the number of antigen-presenting cells in murine lung. Int J Immunopathol Pharmacol. (2008) 21:35-42. doi: 10.1177/039463200802100105

143. Kroker M, Sydlik U, Autengruber A, Cavelius C, Weighardt H, Kraegeloh $\mathrm{A}$, et al. Preventing carbon nanoparticle-induced lung inflammation reduces antigen-specific sensitization and subsequent allergic reactions in a mouse model. Particle Fibre Toxicol. (2015) 12:20. doi: 10.1186/s12989-015-0093-5

144. Jang S, Park JW, Cha HR, Jung SY, Lee JE, Jung SS, et al. Silver nanoparticles modify VEGF signaling pathway and mucus hypersecretion in allergic airway inflammation. Int J Nanomed. (2012) 7:1329. doi: 10.2147/IJN.S27159

145. Park HS, Kim KH, Jang S, Park JW, Cha HR, Lee JE, et al. Attenuation of allergic airway inflammation and hyperresponsiveness in a murine model of asthma by silver nanoparticles. Int J Nanomed. (2010) 5:505. doi: $10.2147 /$ IJN.S11664

146. Silva RM, Anderson DS, Peake J, Edwards PC, Patchin ES, Guo T, et al. Aerosolized silver nanoparticles in the rat lung and pulmonary responses over time. Toxicol Pathol. (2016) 44:673-86. doi: 10.1177/0192623316629804

147. Holland N, Becak D, Shannahan JH, Brown J, Carratt S, Winkle $\mathrm{L}$, et al. Cardiac ischemia reperfusion injury following instillation of $20 \mathrm{~nm}$ citrate-capped nanosilver. J Nanomed Nanotechnol. (2015) 6(Suppl. 6):006. doi: 10.4172/2157-7439.S6-006

148. Comfort KK, Maurer EI, Hussain SM. Slow release of ions from internalized silver nanoparticles modifies the epidermal growth factor signaling response. Colloids Surf B Biointerfaces. (2014) 123:136-42. doi: 10.1016/j.colsurfb.2014.09.008

149. Guo C, Buckley A, Marczylo T, Seiffert J, Römer I, Warren J, et al. The small airway epithelium as a target for the adverse pulmonary effects of silver nanoparticle inhalation. Nanotoxicology. (2018) 12:53953. doi: 10.1080/17435390.2018.1465140

150. Ferdous Z, Al-Salam S, Greish YE, Ali BH, Nemmar A. Pulmonary exposure to silver nanoparticles impairs cardiovascular homeostasis: effects of coating, dose and time. Toxicol Appl Pharmacol. (2019) 367:3650. doi: 10.1016/j.taap.2019.01.006

151. Seiffert J, Hussain F, Wiegman C, Li F, Bey L, Baker W, et al. Pulmonary toxicity of instilled silver nanoparticles: influence of size, coating and rat strain. PLoS ONE. (2015) 10:e0119726. doi: 10.1371/journal.pone.0119726

152. Hussain S, Vanoirbeek JA, Luyts K, De Vooght V, Verbeken E, Thomassen LC, et al. Lung exposure to nanoparticles modulates an asthmatic response in a mouse model. Eur Respir J. (2011) 37:299309. doi: 10.1183/09031936.00168509

153. Barreto E, Serra MF, dos Santos RV, C.dos Santos EA, Hickmann J, Cotias AC, et al. Local administration of gold nanoparticles prevents pivotal pathological changes in murine models of atopic asthma. J Biomed Nanotechnol. (2015) 11:1038-50. doi: 10.1166/jbn.2015.2024

154. Omlor AJ, Le DD, Schlicker J, Hannig M, Ewen R, Heck S, et al. Local effects on airway inflammation and systemic uptake of $5 \mathrm{~nm}$ PEGylated and citrated gold nanoparticles in asthmatic mice. Small. (2017) 13:1603070. doi: 10.1002/smll.201603070

155. Zhang X, Zhong W, Meng Q, Lin Q, Fang C, Huang X, et al. Ambient PM2. 5 exposure exacerbates severity of allergic asthma in previously sensitized mice. J Asthma. (2015) 52:785-94. doi: 10.3109/02770903.2015.1036437

156. Zhao YX, Zhang HR, Yang XN, Zhang YH, Feng S, YU FX, et al. Fine particulate matter-induced exacerbation of allergic asthma via activation of T-cell immunoglobulin and mucin domain 1. Chinese Med J. (2018) 131:2461-73. doi: 10.4103/0366-6999.243551

157. Falcon-Rodriguez CI, De Vizcaya-Ruiz A, Rosas-Pérez IA, Osornio-Vargas ÁR. Segura-MedinaInhalation of concentrated PM2. 5 from Mexico City acts as an adjuvant in a guinea pig model of allergic asthma. Environ Pollution. (2017) 228:474-83. doi: 10.1016/j.envpol.2017.05.050

158. Zhao Y, Zhang H, Yang X, Zhang Y, Feng S, Yan X. Fine particulate matter (PM2.5) enhances airway hyperresponsiveness (AHR) by inducing necroptosis in BALB/c mice. Environ Toxicol Pharmacol. (2019) 68:15563. doi: 10.1016/j.etap.2019.03.013

159. Haikerwal A, Akram M, Sim MR, Meyer M, Abramson MJ, Dennekamp M. Fine particulate matter (PM2.5) exposure during a prolonged wildfire period and emergency department visits for asthma. Respirology. (2016) 21:88-94. doi: 10.1111/resp.12613
160. Borchers-Arriagada N, Horsley JA, Palmer AJ, Morgan GG, Tham R, Johnston FH. Association between fire smoke fine particulate matter and asthma-related outcomes: systematic review and meta-analysis. Environ Res. (2019) 179(Pt A):108777. doi: 10.1016/j.envres.2019.108777

161. Carlsten C, Blomberg A, Pui M. Diesel exhaust augments allergeninduced lower airway inflammation in allergic individuals: a controlled human exposure study (vol 71, pg 35, 2016). Thorax. (2016) 71:3544. doi: 10.1136/thoraxjnl-2015-207399

162. Sofer T, Baccarelli A, Cantone L, Coull B, Maity A, Lin X, et al. Exposure to airborne particulate matter is associated with methylation pattern in the asthma pathway. Epigenomics. (2013) 5:147-54. doi: 10.2217/epi.13.16

163. Nadeau K, McDonald-Hyman C, Noth EM, Pratt B, Hammond SK, Balmes $\mathrm{J}$, et al. Ambient air pollution impairs regulatory T-cell function in asthma. $J$ Allergy Clin Immunol. (2010) 126:845-52.e10. doi: 10.1016/j.jaci.2010.08.008

164. McCormack MC, Breysse PN, Matsui EC, Hansel NN, Peng RD, CurtinBrosnan J, et al. Indoor particulate matter increases asthma morbidity in children with non-atopic and atopic asthma. Ann Allergy Asthma Immunol. (2011) 106:308-15. doi: 10.1016/j.anai.2011.01.015

165. Breysse PN, Diette GB, Matsui EC, Butz AM, Hansel NN, McCormack MC. Indoor air pollution and asthma in children. Proc Am Thoracic Soc. (2010) 7:102-6. doi: 10.1513/pats.200908-083RM

166. McCreanor J, Cullinan P, Nieuwenhuijsen MJ, Stewart-Evans J, Malliarou E, Jarup L, et al. Respiratory effects of exposure to diesel traffic in persons with asthma. N Engl J Med. (2007) 357:2348-58. doi: 10.1056/NEJMoa071535

167. Bousquet J, Schünemann HJ, Samolinski B, Demoly P, Baena-Cagnani CE, Bachert $\mathrm{C}$, et al. Allergic Rhinitis and its Impact on Asthma (ARIA): achievements in 10 years and future needs. J Allergy Clin Immunol. (2012) 130:1049-62. doi: 10.1016/j.jaci.2012.07.053

168. Jutel M. Allergen-specific immunotherapy in asthma. Curr Treat Options Allergy. (2014) 1:213-9. doi: 10.1007/s40521-014-0013-1

169. Scadding GK. Optimal management of allergic rhinitis. Arch Dis Childh. (2015) 100:576-82. doi: 10.1136/archdischild-2014-306300

170. Walker S, Durham S, Till S, Roberts G, Corrigan C, Leech S, et al. Immunotherapy for allergic rhinitis. Clin Exp Allergy. (2011) 41:1177200. doi: 10.1111/j.1365-2222.2011.03794.x

171. Cipriani F, Calamelli E, Ricci G. Allergen avoidance in allergic asthma. Front Pediatr. (2017) 5:103. doi: 10.3389/fped.2017.00103

172. Terreehorst I, Hak E, Oosting AJ, Tempels-Pavlica Z, de Monchy JG, Bruijnzeel-Koomen CA, et al. Evaluation of impermeable covers for bedding in patients with allergic rhinitis. N Engl J Med. (2003) 349:23746. doi: 10.1056/NEJMoa023171

173. Larché M, Akdis CA, Valenta R. Immunological mechanisms of allergen-specific immunotherapy. Nat Rev Immunol. (2006) 6:761. doi: 10.1038/nri1934

174. Noon L. Prophylactic inoculation against hay fever. Lancet. 1911:15723. doi: 10.1016/S0140-6736(00)78276-6

175. Bousquet J, Lockey R, Malling HJ. Allergen immunotherapy: therapeutic vaccines for allergic diseases A WHO position paper. J Allergy Clin Immunol. (1998) 102:558-62. doi: 10.1016/S0091-6749(98)70271-4

176. Calderón MA, Casale TB, Togias A, Bousquet J, Durham SR. DemolyAllergen-specific immunotherapy for respiratory allergies: from meta-analysis to registration and beyond. J Allergy Clin Immunol. (2011) 127:30-8. doi: 10.1016/j.jaci.2010.08.024

177. Kappen JH, Durham SR, Veen HIT, Shamji MH. Applications and mechanisms of immunotherapy in allergic rhinitis and asthma. Ther Adv Respir Dis. (2017) 11:73-86. doi: 10.1177/1753465816669662

178. Casale TB, Stokes JR. Immunotherapy: what lies beyond. J Allergy Clin Immunol. (2014) 133:612-9. doi: 10.1016/j.jaci.2014. 01.007

179. Cox L, Nelson H, Lockey R, Calabria C, Chacko T, Finegold I, et al. Allergen immunotherapy: a practice parameter third update. J Allergy Clin Immunol. (2011) 127:S1-S55. doi: 10.1016/j.jaci.2010.09.034

180. Robinson DS, Larché M, Durham SR. Tregs and allergic disease. J Clin Invest. (2004) 114:1389-97. doi: 10.1172/JCI200423595

181. Fujita H, Soyka MB, Akdis M, Akdis CA. Mechanisms of allergen-specific immunotherapy. Clin Transl Allergy. (2012) 2:2. doi: 10.1186/2045-7022-2-2

182. Cox L, Larenas-Linnemann D, Lockey RF, Passalacqua G. Speaking the same language: the World Allergy Organization subcutaneous immunotherapy 
systemic reaction grading system. J Allergy Clin Immunol. (2010) 125:56974.e7. doi: 10.1016/j.jaci.2009.10.060

183. Scadding GK, Brostoff J. Low dose sublingual therapy in patients with allergic rhinitis due to house dust mite. Clin Exp Allergy. (1986) 16:48391. doi: 10.1111/j.1365-2222.1986.tb01983.x

184. Sivam A, Tankersley M, ACAAI immunotherapy and diagnostics committee. perception and practice of sublingual immunotherapy among practicing allergists in the United States: a follow-up survey. Ann Allergy Asthma Immunol. (2019) 110:194-7.e4. doi: 10.1016/j.anai.2019.03.023

185. Penagos M, Eifan AO, Durham SR, Scadding GW. Duration of allergen immunotherapy for long-term efficacy in allergic rhinoconjunctivitis. Curr Treat Options Allergy. (2018) 5:275-90. doi: 10.1007/s40521-018-0176-2

186. Senti G, von Moos S, Tay F, Graf N, Sonderegger T, Johansen P, et al. Epicutaneous allergen-specific immunotherapy ameliorates grass pollen-induced rhinoconjunctivitis: a double-blind, placebocontrolled dose escalation study. J Allergy Clin Immunol. (2012) 129:128-35. doi: 10.1016/j.jaci.2011.08.036

187. Slovick A, Douiri A, Muir R, Guerra A, Tsioulos K, Hay E, et al. Intradermal grass pollen immunotherapy increases TH2 and IgE responses and worsens respiratory allergic symptoms. J Allergy Clin Immunol. (2017) 139:18309.e13. doi: 10.1016/j.jaci.2016.09.024

188. Hylander T, Larsson O, Petersson-Westin U, Eriksson M, Georén SK, Winqvist $\mathrm{O}$, et al. Intralymphatic immunotherapy of pollen-induced rhinoconjunctivitis: a double-blind placebo-controlled trial. Respir Res. (2016) 17:10. doi: 10.1186/s12931-016-0324-9

189. Weiss R, Hessenberger M, Kitzmüller S, Bach D, Weinberger EE, Krautgartner WD, et al. Transcutaneous vaccination via laser microporation. J Control Release. (2012) 162:391-9. doi: 10.1016/j.jconrel.2012.06.031

190. Kussebi F, Karamloo F, Rhyner C, Schmid-Grendelmeier P, Salagianni M, Mannhart C, et al. A major allergen gene-fusion protein for potential usage in allergen-specific immunotherapy. J Allergy Clin Immunol. (2005) 115:3239. doi: 10.1016/j.jaci.2004.11.041

191. Karamloo F, Grendelmeier S, Kussebi F, Akdis M, Salagianni M, von Beust $\mathrm{BR}$, et al. Prevention of allergy by a recombinant multi-allergen vaccine with reduced IgE binding and preserved T cell epitopes. Eur J Immunol. (2005) 35:3268-76. doi: 10.1002/eji.200425522

192. Asturias J, Ibarrola I, Arilla M, Vidal C, Ferrer A, Gamboa P, et al. Engineering of major house dust mite allergens Der p 1 and Der p 2 for allergen-specific immunotherapy. Clin Exp Allergy. (2009) 39:108898. doi: 10.1111/j.1365-2222.2009.03264.x

193. Creticos PS, Schroeder JT, Hamilton RG, Balcer-Whaley SL, Khattignavong AP, Lindblad R, et al. Immunotherapy with a ragweed-Toll-like receptor 9 agonist vaccine for allergic rhinitis. N Engl J Med. (2006) 355:144555. doi: 10.1056/NEJMoa052916

194. Pfaar O, Nell MJ, Boot JD, Versteeg SA, van Ree R, Roger A, et al. A randomized, 5-arm dose finding study with a mite allergoid SCIT in allergic rhinoconjunctivitis patients. Allergy. (2016) 71:96776. doi: $10.1111 /$ all.12860

195. Hofer H, Asam C, Hauser M, Nagl B, Laimer J, Himly M, et al. Tackling Bet v 1 and associated food allergies with a single hybrid protein. J Allergy Clin Immunol. (2017) 140:525-33.e10. doi: 10.1016/j.jaci.2016.09.055

196. Gallego M, Iraola V, Himly M, Robinson D, Badiola C, García-Robaina J, et al. Depigmented and polymerised house dust mite allergoid: allergen content, induction of IgG4 and clinical response. Int Arch Allergy Immunol. (2010) 153:61-9. doi: 10.1159/000301580

197. Carnes J, Himly M, Gallego M, Iraola V, Robinson DS, Fernandez-Caldas $\mathrm{E}$, et al. Detection of allergen composition and in vivo immunogenicity of depigmented allergoids of Betula alba. Clin Exp Allergy. (2009) 39:42634. doi: 10.1111/j.1365-2222.2008.03132.x

198. Sesardic D, Dobbelaer R. European union regulatory developments for new vaccine adjuvants and delivery systems. Vaccine. (2004) 22:245256. doi: 10.1016/j.vaccine.2003.11.071

199. Gamazo C, D’Amelio C, Gastaminza G, Ferrer M, Irache JM. Adjuvants for allergy immunotherapeutics. Hum Vaccines Immunotherapeut. (2017) 13:2416-27. doi: 10.1080/21645515.2017.1348447

200. Gupta RK. Aluminum compounds as vaccine adjuvants. Adv Drug Deliver Rev. (1998) 32:155-72. doi: 10.1016/S0169-409X(98)00008-8
201. Saint-Lu N, Tourdot S, Razafindratsita A, Mascarell L, Berjont N, Chabre $\mathrm{H}$, et al. Targeting the allergen to oral dendritic cells with mucoadhesive chitosan particles enhances tolerance induction. Allergy. (2009) 64:100313. doi: 10.1111/j.1398-9995.2009.01945.x

202. Win KY, Feng SS. Effects of particle size and surface coating on cellular uptake of polymeric nanoparticles for oral delivery of anticancer drugs. (2005) 26:2713-22. doi: 10.1016/j.biomaterials.2004.07.050

203. Delamarre L, Couture R, Mellman I, Trombetta ES. Enhancing immunogenicity by limiting susceptibility to lysosomal proteolysis. $J$ Exp Med. (2006) 203:2049-55. doi: 10.1084/jem.20052442

204. Al-Awadhi A, Lee Murray J, Ibrahim NK. Developing anti-HER2 vaccines: breast cancer experience. Int J Cancer. (2018) 143:212632. doi: 10.1002/ijc.31551

205. De Rosa SC. Vaccine applications of flow cytometry. Methods. (2012) 57:38391. doi: 10.1016/j.ymeth.2012.01.001

206. Baris S, Kiykim A, Ozen A, Tulunay A, Karakoc-Aydiner E, Barlan I. Vitamin $\mathrm{D}$ as an adjunct to subcutaneous allergen immunotherapy in asthmatic children sensitized to house dust mite. Allergy. (2014) 69:24653. doi: 10.1111/all.12278

207. Hussain M, Javeed A, Ashraf M, Riaz A, Mushtaq MH. Aspirin may do wonders by the induction of immunological self-tolerance against autoimmune atherosclerosis. Med Hypotheses. (2012) 78:1713. doi: 10.1016/j.mehy.2011.10.019

208. Franchi L, Núñez G. The Nlrp3 inflammasome is critical for aluminium hydroxide-mediated IL-1 $\beta$ secretion but dispensable for adjuvant activity. Eur J Immunol. (2008) 38:2085-9. doi: 10.1002/eji.200838549

209. Zielen S, Gabrielpillai J, Herrmann E, Schulze J, Schubert R, Rosewich M. Long-term effect of monophosphoryl lipid A adjuvanted specific immunotherapy in patients with grass pollen allergy. Immunotherapy. (2018) 10:529-36. doi: 10.2217/imt-2018-0004

210. Smarr CB, Yap WT, Neef TP, Pearson RM, Hunter ZN, Ifergan I, et al. Biodegradable antigen-associated PLG nanoparticles tolerize Th2-mediated allergic airway inflammation pre-and postsensitization. Proc Natl Acad Sci USA. (2016) 113:5059-64. doi: 10.1073/pnas.1505782113

211. Munks MW, McKee AS, MacLeod MK, Powell RL, Degen JL, Reisdorph $\mathrm{NA}$, et al. Aluminum adjuvants elicit fibrin-dependent extracellular traps in vivo. Blood. (2010) 116:5191-9. doi: 10.1182/blood-2010-03-2 75529

212. Schülke SS. Induction of interleukin-10 producing dendritic cells as a tool to suppress allergen-specific T helper 2 responses. Front Immunol. (2018) 9:455. doi: 10.3389/fimmu.2018.00455

213. Moingeon P. Adjuvants for allergy vaccines. Hum Vaccines Immunotherapeut. (2012) 8:1492-8. doi: 10.4161/hv.21688

214. Weber M, Niespodziana K, Linhart B, Neubauer A, Huber H, Henning $\mathrm{R}$, et al. Comparison of the immunogenicity of BM32, a recombinant hypoallergenic B cell epitope-based grass pollen allergy vaccine with allergen extract-based vaccines. J Allergy Clin Immunol. (2017) 140:14336.e6. doi: 10.1016/j.jaci.2017.03.048

215. Keating GM. Allergen extract suspension for subcutaneous

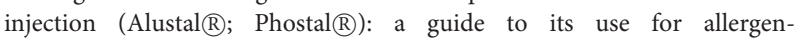
specific immunotherapy. Drugs Therapy Perspect. (2015) 31:175-82. doi: 10.1007/s40267-015-0213-1

216. Klimek L, Uhlig J, Mösges R, Rettig K, Pfaar O. A high polymerized grass pollen extract is efficacious and safe in a randomized double-blind, placebocontrolled study using a novel up-dosing cluster-protocol. Allergy. (2014) 69:1629-38. doi: 10.1111/all.12513

217. Desmet CJ. Adjuvants targeting the DNA sensing pathways-Alum based adjuvants. In: Biological DNA Sensor. Elsevier (2014). p. 271-312.

218. Shardlow E, Mold M, Exley C. Unraveling the enigma: elucidating the relationship between the physicochemical properties of aluminium-based adjuvants and their immunological mechanisms of action. Allergy Asthma Clin Immunol. (2018) 14:80. doi: 10.1186/s13223-018-0305-2

219. Wang Y, Rahman D, Lehner T. A comparative study of stress-mediated immunological functions with the adjuvanticity of alum. J Biol Chem. (2012) 287:17152-60. doi: 10.1074/jbc.M112.347179

220. Hornung V, Bauernfeind F, Halle A, Samstad EO, Kono H, Rock $\mathrm{KL}$, et al. Silica crystals and aluminum salts activate the NALP3 
inflammasome through phagosomal destabilization. Nat Immunol. (2008) 9:847. doi: $10.1038 /$ ni.1631

221. Martinon F. Signaling by ROS drives inflammasome activation. Eur $J$ Immunol. (2010) 40:616-9. doi: 10.1002/eji.200940168

222. Goto N, Kato H, Maeyama JI, Shibano M, Saito T, Yamaguchi J, et al. Local tissue irritating effects and adjuvant activities of calcium phosphate and aluminium hydroxide with different physical properties. Vaccine. (1997) 15:1364-71. doi: 10.1016/S0264-410X(97)00054-6

223. Blumberga G, Groes L, Dahl R. SQ-standardized house dust mite immunotherapy as an immunomodulatory treatment in patients with asthma. Allergy. (2011) 66:178-85. doi: 10.1111/j.1398-9995.2010.02451.x

224. Gherardi RK, F.-J.Authier JL. Macrophagic myofasciitis: characterization and pathophysiology. (2012) 21:184-9. doi: 10.1177/0961203311429557

225. de la Torre MV, Baeza ML, Nájera L, Zubeldia JM. Comparative study of adjuvants for allergen-specific immunotherapy in a murine model. Immunotherapy. (2018) 10:1219-28. doi: 10.2217/imt-2018-0072

226. HogenEsch $\mathrm{H}$. Mechanism of immunopotentiation and safety of aluminum adjuvants. Front Immunol. (2013) 3:406. doi: 10.3389/fimmu.2012.00406

227. Klechevsky E, Liu M, Morita R, Banchereau R, Thompson-Snipes L, Palucka AK, et al. Understanding human myeloid dendritic cell subsets for the rational design of novel vaccines. Hum Immunol. (2009) 70:2818. doi: 10.1016/j.humimm.2009.02.004

228. Klechevsky E, Morita R, Liu M, Cao Y, Coquery S, Thompson-Snipes L, et al. Functional specializations of human epidermal Langerhans cells and CD14+ dermal dendritic cells. Immunity. (2008) 29:497510. doi: 10.1016/j.immuni.2008.07.013

229. Laffont S, Siddiqui KR, Powrie F. Intestinal inflammation abrogates the tolerogenic properties of MLN CD103+ dendritic cells. Eur J Immunol. (2010) 40:1877-83. doi: 10.1002/eji.200939957

230. Denning TL, Norris BA, Medina-Contreras O, Manicassamy S, Geem D, Madan R, et al. Functional specializations of intestinal dendritic cell and macrophage subsets that control Th17 and regulatory T cell responses are dependent on the T cell/APC ratio, source of mouse strain, and regional localization. J Immunol. (2011) 187:733-47. doi: 10.4049/jimmunol.1002701

231. Fehres CM, Garcia-Vallejo JJ, Unger WW, van Kooyk Y. Skin-resident antigen-presenting cells: instruction manual for vaccine development. Front Immunol. (2013) 4:157. doi: 10.3389/fimmu.2013.00157

232. Van Der Lubben IM, Konings FA, Borchard G, Verhoef JC, Junginger HE. In vivo uptake of chitosan microparticles by murine Peyer's patches: visualization studies using confocal laser scanning microscopy and immunohistochemistry. J Drug Target. (2001) 9:39-47. doi: 10.3109/10611860108995631

233. Li GP, Liu ZG, Liao B, Zhong NS. Induction of Th1-type immune response by chitosan nanoparticles containing plasmid DNA encoding house dust mite allergen Der p 2 for oral vaccination in mice. Cell Mol Immunol. (2009) 6:45-50. doi: 10.1038/cmi.2009.6

234. Liu Z, Guo H, Wu Y, Yu H, Yang H, Li J. Local nasal immunotherapy: efficacy of Dermatophagoides farinae-chitosan vaccine in murine asthma. Int Arch Allergy Immunol. (2009) 150:221-8. doi: 10.1159/000222674

235. Razafindratsita A, Saint-Lu N, Mascarell L, Berjont N, Bardon T, Betbeder $\mathrm{D}$, et al. Improvement of sublingual immunotherapy efficacy with a mucoadhesive allergen formulation. J Allergy Clin Immunol. (2007) 120:27885. doi: $10.1016 /$ j.jaci.2007.04.009

236. Machado Y, Duinkerken S, Hoepflinger V, Mayr M, Korotchenko E, Kurtaj A, et al. Synergistic effects of dendritic cell targeting and laser-microporation on enhancing epicutaneous skin vaccination efficacy. J Control Release. (2017) 266:87-99. doi: 10.1016/j.jconrel.2017.09.020

237. Weinberger EE, Himly M, Myschik J, Hauser M, Altmann F, Isakovic A, et al. Generation of hypoallergenic neoglycoconjugates for dendritic cell targeted vaccination: a novel tool for specific immunotherapy. J Control Release. (2013) 165:101-9. doi: 10.1016/j.jconrel.2012.11.002

238. Rodriguez MJ, Ramos-Soriano J, Perkins JR, Mascaraque A, Torres MJ, Gomez F, et al. Glycosylated nanostructures in sublingual immunotherapy induce long-lasting tolerance in LTP allergy mouse model. Sci Rep. (2019) 9:4043. doi: 10.1038/s41598-019-40114-7

239. Sirvent S, Soria I, Cirauqui C, Cases B, Manzano AI, Diez-Rivero CM, et al. Novel vaccines targeting dendritic cells by coupling allergoids to nonoxidized mannan enhance allergen uptake and induce functional regulatory $\mathrm{T}$ cells through programmed death ligand 1. J Allergy Clin Immunol. (2016) 138:558-67.e11. doi: 10.1016/j.jaci.2016.02.029

240. Gonzalez JL, Zalve V, Fernandez-Caldas E, Cases B, Subiza JL, Casanovas M. A pilot study of immunotherapy in dogs with atopic dermatitis using a mannan-Dermatophagoides farinae allergoid targeting dendritic cells. Vet Dermatol. (2018) 29:449-e152. doi: 10.1111/vde.12679

241. Benito-Villalvilla C, Soria I, Subiza JL, Palomares O. Novel vaccines targeting dendritic cells by coupling allergoids to mannan. Allergo J Int. (2018) 27:25662. doi: 10.1007/s40629-018-0069-8

242. Kostadinova AI, Middelburg J, Ciulla M, Garssen J, Hennink WE, L.Knippels MJ, et al. PLGA nanoparticles loaded with betalactoglobulin-derived peptides modulate mucosal immunity and may facilitate cow's milk allergy prevention. Eur J Pharmacol. (2018) 818:211-20. doi: 10.1016/j.ejphar.2017.10.051

243. Hajavi J, Hashemi M, Sankian M. Evaluation of size and dose effects of rChe a 3 allergen loaded PLGA nanoparticles on modulation of Th2 immune responses by sublingual immunotherapy in mouse model of rhinitis allergic. Int J Pharmaceut. (2019) 563:282-92. doi: 10.1016/j.ijpharm.2019.03.040

244. Salari F, Varasteh AR, Vahedi F, Hashemi M, Sankian M. Down-regulation of Th2 immune responses by sublingual administration of poly (lacticco-glycolic) acid (PLGA)-encapsulated allergen in BALB/c mice. Int Immunopharmacol. (2015) 29:672-8. doi: 10.1016/j.intimp.2015.09.011

245. Liu Q, Wang X, Liu X, Kumar S, Gochman G, Ji Y, et al. Use of polymeric nanoparticle platform targeting the liver to induce treg-mediated antigenspecific immune tolerance in a pulmonary allergen sensitization model. ACS Nano. (2019) 13:4778-94. doi: 10.1021/acsnano.9b01444

246. Moingeon P, Batard T, Fadel R, Frati F, Sieber J, Van Overtvelt L. Immune mechanisms of allergen-specific sublingual immunotherapy. Allergy. (2006) 61:151-65. doi: 10.1111/j.1398-9995.2006.01002.x

247. Gomez S, Gamazo C, Roman BS, Ferrer M, Sanz ML, Irache JM. Gantrez AN nanoparticles as an adjuvant for oral immunotherapy with allergens. Vaccine. (2007) 25:5263-71. doi: 10.1016/j.vaccine.2007.05.020

248. Camacho AI, Da Costa Martins R, Tamayo I, de Souza J, Lasarte JJ, Mansilla C, et al. Poly(methyl vinyl ether-co-maleic anhydride) nanoparticles as innate immune system activators. Vaccine. (2011) 29:71305. doi: 10.1016/j.vaccine.2011.05.072

249. Brotons-Canto A, Gamazo C, Martin-Arbella N, Abdulkarim M, Gumbleton M, Quincoces G, et al. Mannosylated nanoparticles for oral immunotherapy in a murine model of peanut allergy. J Pharm Sci. (2019) 108:24219. doi: 10.1016/j.xphs.2019.02.022

250. Uto T, Wang X, Sato K, Haraguchi M, Akagi T, Akashi M, et al. Targeting of antigen to dendritic cells with poly(gamma-glutamic acid) nanoparticles induces antigen-specific humoral and cellular immunity. J Immunol. (2007) 178:2979-86. doi: 10.4049/jimmunol.178.5.2979

251. Broos S, Lundberg K, Akagi T, Kadowaki K, Akashi M, Greiff L, et al. Immunomodulatory nanoparticles as adjuvants and allergen-delivery system to human dendritic cells: implications for specific immunotherapy. Vaccine. (2010) 28:5075-85. doi: 10.1016/j.vaccine.2010.05.004

252. Inomata N, Chin K, Nagashima M, Ikezawa Z. Late-onset anaphylaxis due to poly (gamma-glutamic acid) in the soup of commercial cold Chinese noodles in a patient with allergy to fermented soybeans (natto). Allergol Int. (2011) 60:393-6. doi: 10.2332/allergolint.10-CR-0267

253. Shen L, Li J, Liu Q, Song W, Zhang X, Tiruthani K, et al. Local blockade of interleukin 10 and C-X-C motif chemokine ligand 12 with nano-delivery promotes antitumor response in murine cancers. ACS Nano. (2018) 12:983041. doi: 10.1021/acsnano.8b00967

254. Song W, Tiruthani K, Wang Y, Shen L, Hu M, Dorosheva O, et al. Trapping of lipopolysaccharide to promote immunotherapy against colorectal cancer and attenuate liver metastasis. Adv Mater. (2018) 30:e1805007. doi: 10.1002/adma.201805007

255. Pali-Scholl I, Szollosi H, Starkl P, Scheicher B, Stremnitzer C, Hofmeister A, et al. Protamine nanoparticles with $\mathrm{CpG}$-oligodeoxynucleotide prevent an allergen-induced Th2-response in BALB/c mice. Eur J Pharm Biopharm. (2013) 85(3 Pt A):656-64. doi: 10.1016/j.ejpb.2013.03.003

256. Senti G, Graf $N$, Haug $S$, Ruedi $N$, von Moos $S$, Sonderegger $T$, et al. Epicutaneous allergen administration as a novel method of allergen-specific immunotherapy. J Allergy Clin Immunol. (2009) 124:9971002. doi: $10.1016 /$ j.jaci.2009.07.019 
257. Zeltins A, West J, Zabel F, El Turabi A, Balke I, Haas S, et al. Incorporation of tetanus-epitope into virus-like particles achieves vaccine responses even in older recipients in models of psoriasis, Alzheimer's and cat allergy. NPJ Vaccines. (2017) 2:30. doi: 10.1038/s41541-017-0030-8

258. Kundig TM, Senti G, Schnetzler G, Wolf C, Prinz Vavricka BM, Fulurija A, et al. Der p 1 peptide on virus-like particles is safe and highly immunogenic in healthy adults. J Allergy Clin Immunol. (2006) 117:14706. doi: 10.1016/j.jaci.2006.01.040

259. Senti G, Johansen P, Haug S, Bull C, Gottschaller C, Muller P, et al. Use of A-type $\mathrm{CpG}$ oligodeoxynucleotides as an adjuvant in allergen-specific immunotherapy in humans: a phase I/IIa clinical trial. Clin Exp Allergy. (2009) 39:562-70. doi: 10.1111/j.1365-2222.2008.03191.x

260. Casale TB, Cole J, Beck E, Vogelmeier CF, Willers J, Lassen C, et al. CYT003, a TLR9 agonist, in persistent allergic asthma - a randomized placebocontrolled Phase 2b study. Allergy. (2015) 70:1160-8. doi: 10.1111/all.12663

261. Kratzer B, Kohler C, Hofer S, Smole U, Trapin D, Iturri J, et al. Prevention of allergy by virus-like nanoparticles (VNP) delivering shielded versions of major allergens in a humanized murine allergy model. Allergy. (2019) 74:246-60. doi: 10.1111/all.13573

262. Kresge CT, Leonowicz ME, Roth WJ, Vartuli JC, Beck JS. Ordered mesoporous molecular sieves synthesized by a liquid-crystal template mechanism. Nature. (1992) 359:710-2. doi: 10.1038/359710a0
263. Liberman A, Mendez N, Trogler WC, Kummel AC. Synthesis and surface functionalization of silica nanoparticles for nanomedicine. Surf Sci Rep. (2014) 69:132-58. doi: 10.1016/j.surfrep.2014.07.001

264. Peng X, Liang Y, Yin Y, Liao H, Li L. Development of a hollow mesoporous silica nanoparticles vaccine to protect against house dust mite induced allergic inflammation. Int J Pharm. (2018) 549:11523. doi: 10.1016/j.ijpharm.2018.07.047

265. Castillo RR, Vallet-Regi M. Functional mesoporous silica nanocomposites: biomedical applications and biosafety. Int J Mol Sci. (2019) 20:929. doi: 10.3390/ijms20040929

Conflict of Interest: The authors declare that the research was conducted in the absence of any commercial or financial relationships that could be construed as a potential conflict of interest.

Copyright (C) 2020 Joubert, Geppert, Johnson, Mills-Goodlet, Michelini, Korotchenko, Duschl, Weiss, Horejs-Höck and Himly. This is an open-access article distributed under the terms of the Creative Commons Attribution License (CC BY). The use, distribution or reproduction in other forums is permitted, provided the original author(s) and the copyright owner(s) are credited and that the original publication in this journal is cited, in accordance with accepted academic practice. No use, distribution or reproduction is permitted which does not comply with these terms. 